\title{
Pathobiology of fungal infections of the central nervous system with special reference to the Indian scenario
}

\author{
S. K. Shankar, A. Mahadevan, C. Sundaram*, Chitra Sarkar^, Geeta Chacko\#, D. N. Lanjewar§, \\ Vani Santosh, T. C. Yasha, V. V. Radhakrishnan ${ }^{\dagger}$ \\ Department of Neuropathology, National Institute of Mental Health and Neurosciences, Bangalore, *Department of Pathology, Nizam's Institute \\ of Medical Sciences, Hyderabad, ^Department of Pathology, All India Institute of Medical Sciences, New Delhi, \#Department of Pathology, \\ Christian Medical College, Vellore, ${ }^{\circledR}$ Department of Pathology, Grant Medical College and Sir JJ Group of Hospitals, Mumbai, ${ }^{\dagger}$ Department of \\ Pathology, Sree Chitra Tirunal Institute for Medical Sciences and Technology, Thiruvanathapuram, India
}

\begin{abstract}
Ubiquitously present fungi in the environment find a nidus in the human body and adopt its metabolic machinery to be in symbiosis or become pathogenic. Immunocompromised states like human immunodeficiency virus (HIV) / acquired immunodeficiency syndrome (AIDS), systemic neoplasia and organ transplantation have enhanced the frequency of fungal infections. High-risk behavior, IV drug abuse and air travel have led to the emergence of new fungal infections hitherto geographically localized. The pathology in the central nervous system (CNS) is dictated largely by the size of the fungus - the yeast forms, by virtue of their small size enter the microcirculation to cause meningitis and microabscesses, while hyphal forms invade the vasculature to manifest as large pale or hemorrhagic infarcts. The growth kinetics of fungi, the antigenic character of the capsule. the proteases secreted by the mycelial forms and the biochemical milieu in the host also determine clinical manifestations. A hospitalbased analysis of the available information from India suggests that in the non-HIV patient population, hyphal forms like Aspergillosis and Zygomycosis are the most common pathogens, while yeast forms like Cryptococcus and Candida are the prime pathogens in cases of HIVIAIDS, the altered macrophage function acting in synergy with suppressed cell-mediated immunity. In Northeastern states, systemic infection by Penicillium marneffei is reported in association with HIV though CNS involvement is not recorded. Although fungal infections of the CNS are reported from various hospitals in India, studies are limited by non-availability of relevant microbiological studies and the reported prevalence data is biased by the surgical practices, availability of postmortem and microbiology and laboratory support. Detailed clinical and mycological investigations related to the interaction between the fungus and host environment is a fertile area of research to understand the basic pathogenetic mechanisms.
\end{abstract}

Key words: Aspergillosis, central nervous system, cryptococcosis, dimorphic fungi, mycotic infections, pathogenesis, penicilliosis, pheohyphomycosis, zygomycosis

Fungi are ubiquitous in nature, but the distribution of fungal infections in a community depends on the environment, the climatic conditions, socioeconomic status of the human hosts, their habits and genetic factors. The ability of fungi to adapt to the elevated body temperature and reduced redox state of the tissues and overcome defense mechanisms of the human host alone can cause disease of varying severity. In the soil they are saprophytes producing mycelia and airborne conidia. Normally fungal infections are of low virulence and confined to local infections. In immunocompromised states, however, the same fungus tends to produce invasive infection with devastating consequences. Certain body sites like the brain and meninges are preferentially invaded by specific groups of fungi like Cryptococcus, Candida species. Patients with the acquired immunodeficiency syndrome (AIDS) appear to be more prone to infections by Candida, Cryptococcus, Nocardia, Histoplasma and Pneumocystis carinii while aspergillosis is uncommon. In cases of hematological malignancies, solid organ transplantation, renal failure or autoimmune disorders with prolonged steroid therapy, candidiasis and aspergillosis are common. This reflects the preferential selectivity of the fungus for host metabolic state and immune status favorable for survival and growth. A wide variety of fungi now isolated from neutropenic patients like Pheohyphomycetes, Trichosporum and Penicillium marneffei were not recognized as human pathogens before. Some of the fungi like coccidioidomycosis and histoplasmosis show 
gender preference, the chronic progressive disease being more common in males. In pregnant women the dissemination rate is equal to or exceeds that in males, reflecting the hormonal influence on the growth of fungi. Worldwide travel has increased the exposure of many communities to formally geographically limited fungal infections.

Fungi like Blastomyces dermatitides, Paracoccidioides brasiliensis, Pseudoallescheria boydii and Coccidioides immitis are capable of eliciting disease in the absence of known predisposing factors and are hence labeled pathogenic fungi. It is essential to realize that any fungus is potentially a central nervous system (CNS) pathogen and patients with fungal infections have some degree of immunosuppression. Classification as pathogenic and opportunistic fungi is more for ease of understanding of the pathology as overlap in pathogenesis and invasive patterns exists in both forms.

The morphology and size of the organism determine the evolution and phenotype of CNS lesions. The small yeast forms, up to $20 \mu \mathrm{m}$ in diameter (Blastomyces, Coccidioides, Paracoccidioides, Sporotrichum, Histoplasma, Cryptococcus and Candida) reach the small arterioles and capillaries producing leptomeningitis and subpial ischemic lesions as they have access to the microcirculation from which they seed the subarachnoid space. Intermediate-sized pseudohyphae such as those of Candida occlude small vessels in the microcirculation to produce local areas of tissue necrosis that transform into abscesses. The large hyphal forms of variable size (Septate-Aspergillus, Cephalosporium, Cladosporium etc; non-septate-Zygomyces) obstruct large and intermediate size arteries and occasionally veins, giving rise to large infarcts. Routine histology, special stains and morphological characteristics indicate the type of fungus, but speciation needs culturing and biochemical characterization. Tissue fungal infection burden of less than $10^{3} \mathrm{CFU} / \mathrm{gm}$ of tissue usually proves to be histologically negative. ${ }^{[1]}$

The phenomenon of resistance to fungal infection is poorly understood and most of the data available is extrapolation from animal models. Immunity to fungal infections is related to the tissue reaction elicited by the fungi and their products. ${ }^{[2-4]}$ Unlike superficial fungi, the deep mycosis has diverse antigens with different activities. Fungi like Histoplasma and Blastomyces exist as dimorphic forms having different antigens, $(\mathrm{H}$ and $\mathrm{M}$ antigens) each specific in their molecular features and pathogenic potentials. ${ }^{[5-7]}$ Humoral responses are induced by producing circulatory antibodies to polysaccharides and glycoprotein fractions of the fungal cell wall. The quantitation of the circulating antibodies does not reflect the immune status of the individual and are not protective. In some, profound antigenemia can be found instead of antibody response indicating deficient/indifferent humoral immunity to the antigen. The fungal antigens are highly cross-reactive with even quite unrelated fungal antigens..$^{[5,8]}$ In deep tissue mycosis, the antigen of the infective yeast is quite different from that found in cultures with spores and mycelium. Both humoral and cell-mediated immunity take part to contain the fungus and a high degree of overlap in immune response is exhibited. The immunity against fungi is not long-lasting unlike in bacteria and viruses, the antigenic potential being variable, highly nonspecific and relatively poor to elicit response. This makes the host prone for reinfection by the same fungus at the previously infected site, despite healing of the existing infection in the individual.

Nonspecific (innate) defense mechanisms to fungal infections include skin and mucosa behaving as mechanical barriers and cytokines facilitating emigration of phagocytic cells (polymorphs and macrophages) to ingest and destroy the microbes. Neutrophils, the first line of defense against microbes are short-lived cells that have powerful antifungal and bactericidal mechanisms. Macrophages are long-lived and form the first line of defense against inhaled microbial pathogens, like Aspergillus spores. T lymphocytes in conjunction with macrophages are important in conferring specific resistance to fungal infection.

Fatal fugal infections are uncommon among patients with intact immunological defense and are caused by restricted number of 'pathogenic' fungi. In immunocompromised patients, the protective mechanisms are deficient or absent making them prone to infections from saprophytic fungi that are generally nonpathogenic in immunocompetent hosts. Disseminated and progressive infection caused by Penicilliosis marneffei is an emerging opportunistic infection in AIDS patients and is endemic in Southeast Asia and Southern China.

The following presentation centers more on the patholobiology of common fungal infections of CNS relevant to India while rare and emerging fungi invading the brain are dealt with briefly. Though fungal infections of the nervous system are reported from various centers in India [Table 1], the studies are limited by non-availability of relevant mycological studies. The prevalence data of fungal infections from various centers [Table 1] is to a certain extent biased because of the surgical practices and limited availability of postmortem studies. In view of the large number of autopsies from AIDS cases, the National Institute of Mental Health and Neurosciences (NIMHANS) at Bangalore has the highest number of cases of cryptococcosis followed by aspergillosis. On the other hand, academic institutions from Hyderabad,${ }^{[9]}$ Chandigarh $^{[10]}$ and Bangalore reported large series of aspergillosis derived from surgical material. The low numbers of cryptococcosis reported by other centers may therefore not be a true reflection of low prevalence. The advent of organ transplantation 
Table 1: Central nervous system fungal infections reported from different centers in India

\begin{tabular}{|c|c|c|c|c|c|c|}
\hline & No. of cases & Aspergillus & Zygomycosis & Pheohyphomycosis & Cryptococcosis & Candida \\
\hline NIMHANS, Bangalore & $180(1978-2006)$ & $55(16)$ & $33(10)$ & $14(7)$ & $78(71)$ & - \\
\hline NIMS, Hyderabad & $154(1988-2006)$ & $89(28)$ & $52(11)$ & $04(2)$ & $03(1)$ & $06(3)$ \\
\hline PGIMER, Chandigarh & 146 (1980-1999) & 66 & 57 (15) & - & 12 & 11 \\
\hline AlIMS, New Delhi & 36 (1996-2006) & 29 & 05 & 02 & - & - \\
\hline CMC, Vellore & $18(1987-2006)$ & 12 & 03 & 02 & - & 01 \\
\hline SCTIMCT, Trivandrum & NA & 4 & & - & - & 01 \\
\hline
\end{tabular}

Figures in parentheses indicate culture-confirmed cases

with immunosuppressive therapy and HIV/AIDS has altered the prevalence data of systemic fungal infections in many centers reflecting the vulnerable population than changes in the environmental ecosystems. Newer forms of fungal infections are emerging as a result of global travel.

\section{Cryptococcosis}

Cryptococcosis is a deep visceral, systemic cutaneous mycosis with reports from worldwide and in all races. Male predominance can be explained partly by greater outdoor exposure and partly by the fact that hormonal, estrogen inhibits the growth of Cryptococcus. ${ }^{[11]}$ For reasons not clear, person to person transmission of this illness is not reported. More than $50 \%$ of patients with disseminated disease are immunocompromised. On the other hand, patients with cryptococcomas, a granulomatous mass lesion, are not immunocompromised. Patients with AIDS or other immunocompromised states are almost exclusively infected with $C$. neoformans variety neoformans (Serotypes A,D, A/D) while C. neoformans var gatti (Serotypes B and C) has a propensity to cause disease in immunocompetent hosts, suggesting that genetic and phenotypic differences are responsible for the different severity of the disease. ${ }^{[12,13]}$

The fungus is most frequently isolated from pigeon droppings, but also from soil, wood and trees. ${ }^{[14,15]}$ Cryptococcus var gatti is mostly limited to tropical and subtropical regions. Molecular epidemiology of C. neoformans has revealed genetic variation between isolates. High degree of heterogeneity is noted among isolates from USA, while isolates from most areas of the world, including Australia, show limited genetic diversity, with possible clonality. ${ }^{[16-18]}$

Cryptococcus produces capsular antigen glucoronoxylomannan in large quantities, which is heatstable and pronase-resistant and its half life is $24 \mathrm{~h} .{ }^{[19]}$ False positive tests by latex agglutination tests (RPLA) for cryptococcosis may occur by cross-reactivity with heatstable components of Trichosporon bigelii, malignancy, septicemia and contamination of talc from latex gloves into cerebrospinal fluid (CSF). ${ }^{[20]}$ Non-capsular exoantigens from both encapsulated and unencapsulated isolates of $\mathrm{C}$. neoformans like species-specific $34-38 \mathrm{kDA}$ glycoprotein $^{[21]}$ and $115 \mathrm{kDA}$ exoantigen react strongly with sera of patients with cryptococcosis and are thus useful in diagnosis of cryptococcosis in AIDS patients. ${ }^{[22]}$ Antigen titer levels in HIV patients with cryptococcal infection remain elevated for a longer time and these patients may require a longer duration of treatment.

Majority of C. neoformans isolates identified before AIDS epidemic in Thailand belonged to Serotype B and $\mathrm{C}$ (C. neoformans var gatti) while most of the isolates now are Serotype A and D (Cryptococcus neoformans var neoformans). In contrast to relatively uniform colony characteristics of Candida species, variation in colony characters has been reported in cases of cryptococcosis. Melanin positive cryptococci are pathogenic while melanin negative albino isolates are considered nonpathogenic. ${ }^{[23]}$ However, Banerjee ${ }^{[23]}$ isolated melanin negative albino strains and melanin positive and negative strains of $C$. neoformans (var grubii) in patients with HIV, suggesting a molecular genetic variation. Most of the isolates from HIV positive patients from India are serotype A, var grubbi. In a study by Rajendran et al. from south India ${ }^{[24]}$ of the 12 isolates from HIV positive individuals, 10 were VNI (Serotype A) molecular type. In previous studies in immunocompromised patients, strains of variety neoformans, particularly Serotype A were isolated. ${ }^{[23]}$ Identification of var gatti is essential as this variety is relatively refractory to treatment and needs prolonged or increased dose of antifungal therapy and shows long-term sequelae.

Most commonly Cryptococcus initiates as a primary pulmonary infection. Approximately $5-10 \%$ of HIV infected patients develop cryptococcal meningitis (CM) as an AIDS defining illness ${ }^{[25]}$ and in about $40 \%$, it may be the initial manifestation. ${ }^{[26]}$ Of the 588 patients with HIV/ AIDS analyzed (1990-2002) at NIMHANS, Bangalore, south India, cryptococcosis was the opportunistic infection in 25\% and cryptococcosis and tuberculosis with coexisting toxoplasmosis in $12 \%$ (Satishchandra P, Unpublished data). A clinical study from western India reported cryptococcal meningitis in $67.4 \%$ of cases. ${ }^{[27]}$ In an autopsy study of 134 cases of HIV/AIDS from NIMHANS between 1990-2004, cryptococcal infection accounted for $31.3 \%$ of monomicrobial infections, toxoplasmosis for $20.8 \%$ and tuberculous meningitis for $20.1 \% .{ }^{[28]}$ This discrepancy between clinical and autopsy data may be related to misdiagnosis of systemic cryptococcal infection as tuberculous infection because of close clinical and radiological similarities and also 
tuberculosis being highly endemic in India. It is likely that cryptococcal meningitis in cases of HIV could be reactivation of the dormant lesion in the lung similar to Ghon's focus of pulmonary tuberculosis. The systemic infection of Cryptococcus from the primary pulmonary and cutaneous focus is essentially hematogenous. The spread to the brain most often results in leptomeningitis similar to tuberculosis. CSF low in complement and immunoglobulins facilitates establishment of infection in the basal meninges and choroid plexus. Cryptococcal CNS infections can be meningitis, meningoencephalitis or rarely cryptococcomas, as localized granulomatous masses. Cryptococcosis in childhood AIDS has been diagnosed more frequently than in pre-AIDS era. ${ }^{[29]}$

Grossly, the pathological lesions can be minimal and overlooked, mistaking the slightly opaque meninges as pooling of CSF in subarachnoid space [Figure 1A]. On occasion, small nodules $2-3 \mathrm{~mm}$ in size, adjacent to the vessels on the surface may be seen, mistaken for tuberculous lesion. Cryptococcal meningitis tends to be subacute or chronic and may be associated with hydrocephalus in patients with longer survival due to chronic fibrosing leptomeningitis along the base. In less than $10 \%$ of cases, one finds multiple, cystic, nongranulomatous, mucoid intraparenchymal lesions in the basal ganglia [Figure 1B], thalamus, cortical ribbon and ventral brainstem, suggesting hematogenous spread of the fungus and entrapment around the endarteries of the pial, lenticulostriate and thalamostriate vessels. Rarely, large demyelinating lesions resembling demyelinating plaques on imaging and gross pathology, are seen, reflecting dispersal of the organism along the medullary

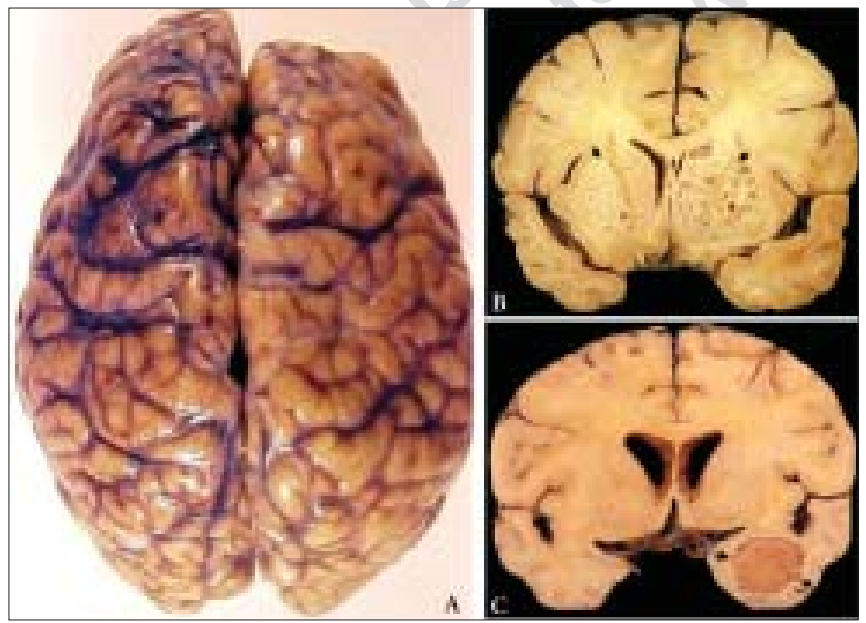

Figure 1: Gross images of the brain showing a diffuse mucoid, gelatinous exudate covering the superolateral surface of the brain (A). Coronal slice highlights multiple punched out pseudocystic lesions in the basal ganglia (arrows) reflecting hematogenous spread (B). Note relative absence of cerebral edema. A rare case of cryptococcoma in the right temporal lobe (C, arrows) resembling a tuberculoma. The lesion is firm, surrounded by tiny cystic spaces along the margin suggesting cryptococcal etiology arteries and veins traversing the white matter following blockage of the superior sagittal sinus. In rare instances in immunocompetent individuals, masses of fungi aggregate in granulomatous exudate producing firm, dry mass lesions in the parenchyma, ependymal surface or choroid plexus.

Histologically, the tissue reaction in cryptococcosis is variable. In meningitis the subarachnoid space is widened by the cryptococci floating in pools of mucin, aggregating around the vessels, but rarely found in the lumen or the vessel wall. The inflammatory reaction is minimal constituted by lymphocytes, plasma cells and foamy histiocytes, which have ingested the organisms. In the gelatinous cystic lesions the neuropil is pushed around the cavity filled by a colony of organisms, usually around a vessel visualized as hypodense areas of widened Virchow Robin space on magnetic resonance imaging (MRI). Gliosis and inflammatory components are conspicuous by their absence in the cystic lesions and when present, the cellular response is restricted to sparse foamy histiocytes.

In case of cryptococcomas, the mass is discernable on imaging. These form circumscribed masses with

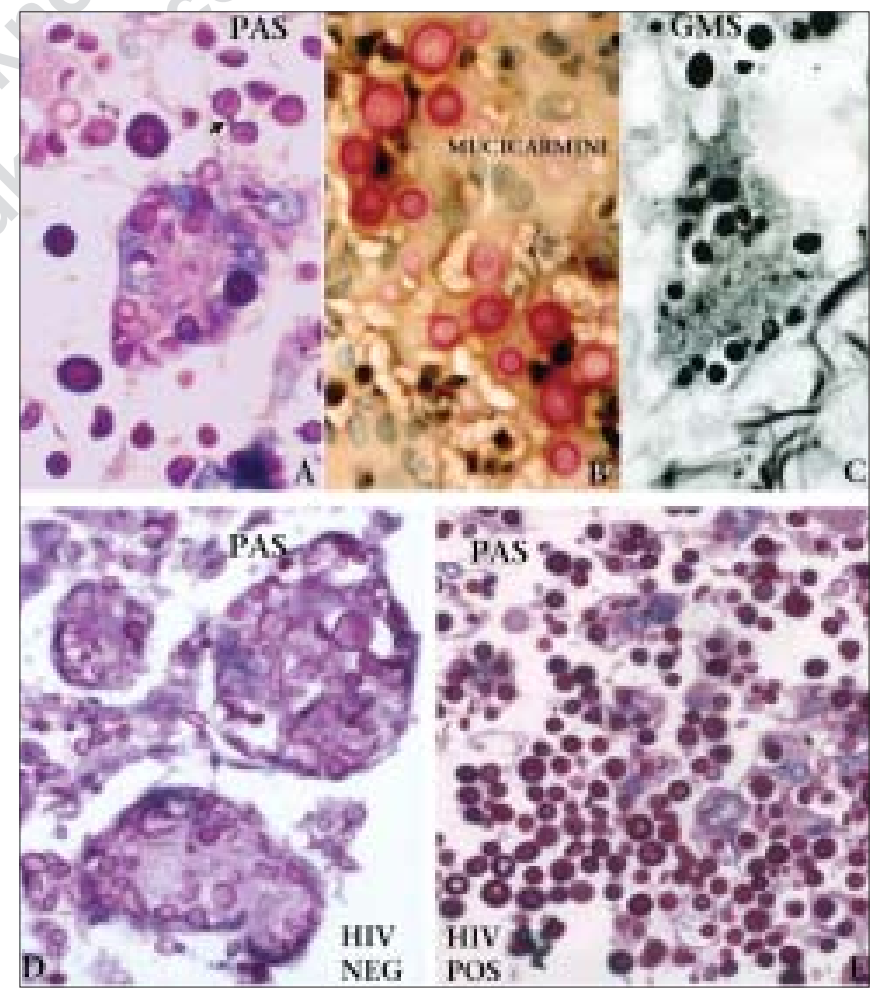

Figure 2: Histochemical stains highlighting the characteristics of cryptococci. The yeast forms have a glycoprotein-rich cell wall labeled by Periodic-acid Schiff (PAS) stain (A) while the mucopolysaccharide component of the capsule is stained by mucicarmine stain (B). The cell wall of the yeast forms are also stained by methenamine silver (GMS) but not the capsule (C). In HIV negative cases, a robust host response is evident by the presence of multinucleate giant cells engulfing the cryptococci (D). In contrast, in immunosuppressed states (HIV positive), the host cell response is poor and numerous extracellular organisms are seen (E). [A: PAS, x320; B: Mucicarmine, x720; C: GMS, x320; D: PAS, $x 600$; E: PAS, $x 320]$ 
tiny cystic spaces along the margin [Figure 1C] or lobulated septate mucoid masses with variable number of giant cells containing the yeast forms devoid of their capsule and zones of necrosis. Rarely, one may find granulomatous arteritis, resembling tuberculous pathology, but PAS stain unmasking the organism in giant cells [Figure 2A-E]. The giant cell response is prominent in immunocompetent hosts [Figure 2D] while in immunocompromised hosts as in HIV/AIDS, the immune response is poor and numerous extracellular yeast forms floating in pools of mucin are seen in the subarachnoid [Figure 2E] and Virchow Robin spaces within the parenchyma.

The polysaccharide capsule sensitive to hyalase, is essential for virulence, inhibiting phagocytosis and antigen presentation. The polysaccharide antigen released during the infection, may spread in the interstitial space of the nervous system and depress the function of immune effector cells, inhibit leukocyte migration, elicit suppressor responses, resulting in antibody unresponsiveness and facilitate invasion of T lymphocytes by the HIV virus. Radhakrishnan et al., ${ }^{[30]}$ demonstrated in an in vivo experimental study that hyaluronidase administration depolymerizes the capsular mucopolysaccharide and elicits a granulomatous response. In addition, endogenous nitric oxide (NO) produced by macrophages and activated astrocytes (activated by IL-1 $\beta$ produced by activated microglia and IFN $\gamma$ by $\mathrm{T}$ cells) inhibit the growth of cryptococci in vitro. The role of this mechanism in vivo is unclear, especially in the absence of reactive astrocytosis in the CNS lesions. The paucity of inflammation and compression of the vessels in the cystic lesions accounts for relatively nonspecific imaging findings except for widened Virchow Robin spaces. Severe headache and elevated intracranial pressure without accompanying hydrocephalus or cerebral edema are reported in more than $50 \%$ cases of cryptococcal meningitis in association with HIV infection. ${ }^{[31]}$ A preliminary pathological study of the brain and the dural venous sinuses in our autopsied cases revealed plugging of the arachnoidal villi by myxoid capsule-rich cryptococci, at places almost occluding the venous sinuses. ${ }^{[28]}$ Lee and colleagues by immunohistochemistry showed tissue deposits of capsular antigen dissociated from the organisms. ${ }^{[32]}$ This obstruction to venous drainage and impedance to CSF circulation could be leading to 'dynamic hydrocephalic attacks' unrecognized on cranial computerized tomography scan or MRI in the majority of instances. Relief obtained by draining off the CSF gives further credence to the idea of dynamic hydrocephalus. Poor CSF inflammatory cell response, positive culture of cryptococci from extraneural sites and systemic dissemination were found to be common in association with HIV and indicated poor prognosis. ${ }^{[33]}$
Cryptococcus neoformans infection though has significant affinity for CNS, rarely results in infarction. Till date six known cases of cerebral infarction and two cases of transient neurological deficit related to cryptococcal meningitis in HIV infected individuals have been reported. Tjia et al., reported $4 \%$ incidence of cerebral infarction secondary to cryptococcal meningitis in HIV seronegative patients. ${ }^{[34]}$ Evidence of arteritis on angiography has been observed in a patient with cryptococcal meningitis. Cryptococcal vasculitis in chronic cases, immune-mediated vasospasm and dilated ventricles stretching the already compressed vessels in the parenchyma by the cryptococcal deposits have been considered as the pathogenetic events leading to infarcts. ${ }^{[35]}$ A case of verterbrobasilar stroke presumably caused by basilar artery occlusion by cryptococcal infection has been described..$^{[36]}$

With the advent of HAART, the incidence of C. neoformans infection in HIV infected patients has declined and immunocompromised organ transplant recipients are at a higher risk. Hussain et al. reported that transplant recipients receiving tacrolimus were significantly less likely to have CNS involvement and more likely to have cutaneous, soft tissue and osteoarticular involvement compared to patients receiving non-tacrolimus-based immunosuppressive therapy. ${ }^{[18]}$ Tacrolimus, a natural macrolide antifungal agent is toxic to $\mathrm{C}$. neoformans in vitro by inhibiting calcineurin, at $37^{\circ} \mathrm{C}$, but not at $24^{\circ} \mathrm{C}$. Thus temperaturedependent inhibition of cryptococci by tacrolimus which crosses the blood brain barrier may prevent CNS infection, but allow growth of fungus at cooler body sites like skin, soft tissues and bone.

\section{Indian literature [Table 2]}

Cryptococcal meningitis has been reported as the most common opportunistic infection of the CNS in patients with HIV/AIDS in India. ${ }^{[27,28,37,38]}$ It accounted for 2-7\% of all opportunistic infections in three large cohorts of HIV patients from Mumbai (4.7-7\%), Chennai (2\%) and Delhi (3.7\%). ${ }^{[39-43]}$ A review of CNS cyrptococcosis in the Indian subcontinent in $2001^{[44]}$ noted peculiarly higher incidence from north India as compared to the south despite high prevalence of HIV in the south as compared to the north Indian states, probably due to under-reporting of cases.

At NIMHANS, cryptococcal meningitis was the most common opportunistic infection in AIDS patients at autopsy [Table 2] seen in $31.3 \%$ of cases. ${ }^{[28]}$ Among the 78 cases of cryptococcal meningitis diagnosed by autopsy/biopsy, Cryptococcus neoformans was the common isolate. In south Indian patients, diagnosis of cryptococcal meningitis was associated with a sevenfold increase in mortality. ${ }^{[39]}$ The mean CD4 count at presentation was $91 \mathrm{cells} / \mu \mathrm{l}$, median survival after 
Table 2: Cryptococcal meningitis reported from India

\begin{tabular}{|c|c|c|c|}
\hline $\begin{array}{l}\text { Cryptococcosis } \\
\text { NIMHANS, Bangalore } \\
n=78 \\
\text { (1990-2006) } \\
\text { Age range: } 6-62 \text { yrs } \\
M: F=5.5: 1\end{array}$ & $\begin{array}{l}\text { Clinical presentation } \\
\text { Meningitis-78 } \\
\text { Cryptococcoma-04 } \\
\text { Infarction-02 } \\
\text { Intraventricular } \\
\text { mass lesion-01 }\end{array}$ & $\begin{array}{l}\text { Predisposing factor } \\
\text { HIV-60 } \\
\text { HIV negative-18 } \\
\text { Steroid therapy-01 }\end{array}$ & $\begin{array}{c}\text { Associated infections } \\
\text { Tuberculous meningitis-06 } \\
\text { Toxoplasma encephalitis-06 } \\
\text { CMV encephalitis-01 } \\
\text { Tuberculous meningitis + } \\
\text { toxoplasma encephalitis-01 }\end{array}$ \\
\hline $\begin{array}{l}\text { Grant Medical College, Mumbai }{ }^{[41]} \\
\mathrm{n}=7 \\
(1988-1996) \\
\text { Age range: } 18-55 \text { yrs }\end{array}$ & $\begin{array}{c}\text { Meningitis-7 } \\
\text { Choroid plexitis-01 }\end{array}$ & HIV-07 & CMV-01 \\
\hline $\begin{array}{l}\text { SGPGI, Lucknow }{ }^{[47]} \\
\mathrm{N}=54 \\
(1992-2004) \\
\text { Age range: Not available }\end{array}$ & Meningitis-54 & $\begin{array}{c}\text { HIV positive-13 } \\
\text { HIV negative-18 } \\
\text { Renal transplant-9 } \\
\text { Diabetes-4 } \\
\text { SLE-1 } \\
\text { Not known-9 } \\
\text { (Data available in } 45, \cdots, e\end{array}$ & Nil \\
\hline
\end{tabular}

diagnosis being 22 months. In a study that included HIV positive and negative cases, those with HIV had poorer CSF cell response and higher mortality. ${ }^{[33]}$ Other poor prognostic factors identified included altered mental status, positive blood cultures, CSF antigen titer above 1:1024, positive CSF India ink, CSF white cell count below $20 \mathrm{cell} / \mathrm{mm}^{3}$ and elevated CSF pressures.

Sporadic reports of cryptococcal meningitis in apparently healthy hosts are reported from different parts of India. ${ }^{[45-47]}$ A single case of cryptococcoma in an immunocompetent host in the absence of cryptococcal meningitis was reported from Mumbai. ${ }^{[48]}$ Besides HIV/AIDS, renal transplantation, diabetes mellitus ${ }^{[47,49]}$ following long-term steroid therapy for polymyositis ${ }^{[50]}$ and acute lymphoblastic leukemia ${ }^{[51]}$ are emerging as risk factors.

The majority of isolates from HIV positive patients from India are Serotype A var grubbi consistent with the serotype prevalent worldwide ${ }^{[14,52,53]}$ and a few reports of var gatti. ${ }^{[54]}$

\section{Candidiasis}

Candida is an endogenous pathogen, its usual habitat being the gastrointestinal tract. Most cases of candidiasis arise in immunocompromised hosts. Phagocytosis is the principal nonspecific mechanism protecting the host against Candida albicans infection. The hyphal form of candida is more pathogenic as it can resist digestion by both polymorphs and macrophages. The Candida albicans mannan is chemotactic to neutrophils and induces complement activation via alternate complement pathway. High incidence of candidiasis is seen in neutropenic patients (cancer patients on chemotherapy), in those with defects in neutrophil/macrophage function (long-term steroid therapy) or depletion of complement (e.g. systemic lupus erythematosis). Role of T-cell mediated immunity in host protection is unclear but is derived from the knowledge that patients with chronic mucocutaneous candidiasis have functional defects in T-cells. Its role in deep-seated infection is less clear.

Mucocutaneous candidiasis is probably one of the commonest manifestations of HIV positive status worldwide, its reported incidence in India being 50$100 \% \cdot{ }^{[55-58]}$ Common agents isolated from India are C. albicans while $C$. dubliniensis is one of the important species reported as an opportunistic organism from western countries ${ }^{[59]}$ and is not seen in the Indian HIV positive population. During the past two decades, a significant shift in the epidemiology of candidemia due to different Candida species has occurred, probably related to antifungal prophylaxis. In the 1960s and 1970s Candida albicans accounted for $90 \%$ of candidemia, while after 1988 Candida tropicalis, C. parapsidosis, C. krusei and C. glabrata became more frequent. ${ }^{[60,61]}$ Candida species colonizing mucocutaneous areas as saprophytes may invade the CNS by blood stream infection, following IV administration of therapeutic drugs or IV drug abuse or during open heart surgery. A wide variety of conditions like prolonged antibiotics, steroids, immunosuppressive agents, chemotherapeutic treatment, indwelling catheters, parenteral nutrition, abdominal surgery, burns, malignancies, neutropenia and HIV/AIDS promote hematogenous spread. ${ }^{[62,63]}$ Candida meningitis can manifest spontaneously as a complication of accidental inoculation during neurosurgery, ${ }^{[64]}$ head injury ${ }^{[65]}$ or ventriculostomies, ${ }^{[66]}$ the severity dictated by the dose of inoculum. ${ }^{[67]}$

The involvement of the CNS is in the form of microabscesses, usually in the territory of the anterior and middle cerebral arteries. ${ }^{\left[{ }^{[8]}\right.}$ With occlusion of small vessels by the pseudohyphae, colonies of yeast enmeshed in fibrin and acute polymorph reaction may present as small hemorrhagic infarcts, progressing to microabscess and later granulomatous reaction. On histology, unless suspected and looked for, the Candida organisms may be overlooked.

Candida cell wall mannans (carbohydrate homopolymer 
with mannose and small amount of protein and phosphate) is a heat-stable antigen, resistant to cooking, protease treatment and acidic $\mathrm{pH}$. The greatest limitation of mannan detection for diagnosis is the transient antigenemia ${ }^{[69]}$ and binding of mannan to immune complexes. Presence of candidal cytoplasmic enzyme, enolase $(48 \mathrm{kDa})$ appears to be a marker for deep tissue invasion even in the absence of detectable fungemia, especially hepato-splenic candidiasis. ${ }^{[70]}$ Aspartyl protease is an important virulence factor expressed by invading $C$. albicans allowing penetration of the anatomical barrier and escape from phagolysosomes. ${ }^{[71]}$ Development of diagnostic tests based on protease detection is of limited value as different species of Candida secrete antigenically distinct proteases.

\section{Indian literature}

Indian literature on CNS candidiasis is sparse. Sundaram et al..99 reported six patients [Table 1] while Radhakrishnan and co-workers reported two patients presenting with multiple intracerebral abscesses $^{[72]}$ and neither had any detectable form of immunocompromised state. In a study from Indore, examining the causes of fungal meningitis in HIV positive and negative subjects, candida was found to be second most common cause of fungal meningitis in both groups after cryptococcal meningitis. ${ }^{[49]}$ In the HIV negative group, diabetes, renal transplantation and small for date and premature neonates have been recognized as causes of immunosuppression. At NIMHANS, candidiasis was seen as a co-infection with $A$. fumigatus and Zygomycetes in two cases. Both had uncontrolled diabetes and one had undergone renal transplantation but no case of isolated CNS candidiasis was seen.

\section{Aspergillosis}

Aspergillus is a ubiquitous fungus in soil, water, decaying vegetation and organic debris that was first recognized to be pathogenic in humans in $1847,{ }^{[73]}$ common pathogenic species being Aspergillus fumigatus or Aspergillus flavus. The asexually produced conidia on aerial hyphal stalk are the infective form of the organism that is inhaled through the respiratory route. Its germination into filamentous forms results in tissue destruction and disease.

The clinical manifestations are produced by both tissue invasion and the host immune response. The first line of cellular defense against conidia that escape entrapment by bronchial mucus are macrophages which ingest the conidia, kill germinating cells and secrete cytokines and chemokines. Alveolar macrophages prevent spores from germinating but are not eliminated. Steroid prevents fusion of phagosome containing aspergillus spores with lysosomes predisposing to profuse germination and dissemination of the infection. Germinating hyphae that escape macrophage surveillance are destroyed by neutrophils and monocytes. Importance of neutrophils in host defense against aspergillus infection is derived from its occurrence in patients with leukemia, neutropenic states and chronic granulomatous disease. T-cells play a role in the resolution of chronic forms by modulating the function of macrophages.

The clinical manifestations and disease severity are dictated by the immunologic state of the patient. Lowered host resistance caused by underlying debilitating diseases such as bronchiectasis, carcinoma, sarcoid and tuberculosis, neutropenia, collagen vascular disorders, organ transplantation, chemotherapy, hepatic failure, disruption of normal flora by use of antimicrobial agents and steroids predispose the patient to colonization and invasive disease. ${ }^{[74-81]}$

Infection of the CNS by Aspergillus follows hematogenous seeding (lungs and heart being the most common primary sites ${ }^{[74,75]}$ or direct inoculation into the CNS during surgical procedures or spread from contiguous structures like paranasal sinuses, mastoid and middle ear. A spectrum of diseases with more than one pathological process can be present at any given time. The morphological changes observed in aspergillosis of CNS depends on the mode of acquisition, whether by hematogenous dissemination or local spread from contiguous anatomical structures. The former leads to multiple lesions involving the middle or anterior cerebral arterial territory with acute necrotizing and purulent lesions (cerebrovascular aspergillosis). In the latter event, the resultant lesions are chronic granulomas eliciting dense fibrosis. The infection in the nervous system can be found in the cerebral parenchyma, meninges or the vascular system.

Aspergillus fumigatus is the most common species to cause invasive disease, the variation in epidemiology, pathogenicity and antifungal susceptibility patterns dictating important differences in the clinical manifestations, therapy and outcome of disease caused by the Aspergillus species. Aspergillus flavus has been implicated as the cause of a large proportion of paranasal sinus infections ${ }^{[82]}$ and Aspergillus nidulans in chronic granulomatous disease. Acquisition of the type of organism also differs with the environmental source, for instance Aspergillus niger, a frequent colonizer of the gastrointestinal tract is recovered from hospital water distribution system ${ }^{[83]}$ while A. terreus is acquired through nosocomial exposure to plants. ${ }^{[84]}$ Aspergillis terreus though an uncommon cause of invasive disease, is resistant to amphotericin B and therefore associated with high mortality. ${ }^{[85]}$ Therefore mycological identification of Aspergillus spp. in making therapeutic decisions cannot be overemphasized.

Intracranial aspergillomas are solid, firm intracerebral lesions that exhibit florid granulomatous inflammation without suppuration [Figures 3A, 3B] observed in 
otherwise immunocompetent individuals and those with chronic granulomatous disease, following hematogenous seeding or extension from contiguous paranasal sinuses. The chronic indolent form of paranasal sinus aspergillosis becomes invasive to involve the orbit, base of skull, anterior, middle and posterior cranial fossae and the parasellar regions to produce intracranial granulomas, usually termed the sinocranial or rhinocerebral form. Extension from the sinuses via the orbital apex is the most common route presenting as orbital apex syndrome and radiological abnormalities lead to early biopsy and

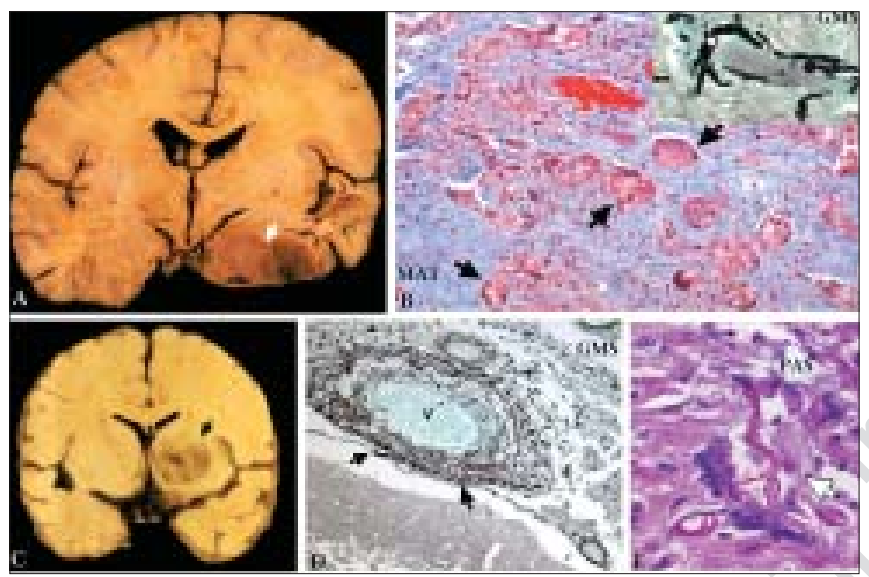

Figure 3: Basitemporal aspergilloma (arrow) arising from the middle cranial fossa and firmly adherent to the brain (A). Histology reveals characteristic multinucleate giant cells (arrows) devoid of lymphocytic reaction and necrosis dispersed in fibrous stroma. Inset (B) highlights intracytoplasmic branching hyphae within these giant cells. Invasive aspergillosis causing hemorrhagic necrosis of basal ganglia (arrow) indicating hematogenous spread (C). Methenamine silver stains clearly demonstrate vascular invasion traversing the vessel (V) wall by hyphal forms of fungi (arrows, D). The septate acute angled branching nature of Aspergillus hyphae (arrows) are seen in the extracellular space (E).

[B: Masson trichrome, x160; B inset: Methenamine silver, x600; D: Methenamine silver, x160; E: PAS, x600]
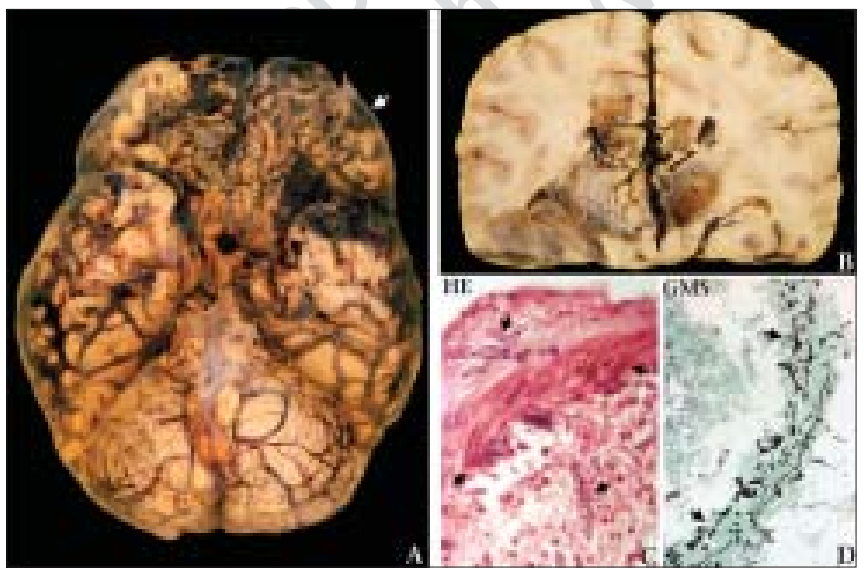

Figure 4: Basal view of the brain showing superficial hemorrhagic necrosis involving the basifrontal areas and temporal poles (A, arrows) by contiguous spread of fungal infection from paranasal sinuses. Coronal slice reveals extensive hemorrhagic necrosis of thalamus, hippocampus and corpus callosum in a case of invasive Zygomycosis (B). Histology of an artery shows transmural invasion by broad aseptate fungi (D). Silver methenamine stain further highlights invasion of vessel wall (arrows), the hyphae being found both in the lumen and extravascular (D) area. [C:HE, x720, D: Silver methenamine (GMS), x160] diagnosis. ${ }^{[86-91]}$ Vascular invasion is not a prominent feature, hence necrosis is rare and vessels are sclerosed. The pathogenetic mechanism of intense fibrosis has been attributed to 'fumigalin' produced by A. fumigatus. ${ }^{[92]}$ However, most cases of sinonasal aspergillosis are caused by A. flavus that predominates in the nasal polyps and hence pathogenesis of characteristic fibrosis remains obscure.

The frontal and temporal lobes are the most common sites for intracerebral granuloma formation ${ }^{[93-96]}$ presenting as space-occupying lesions. ${ }^{[87,97,98]}$ Those located at the basifrontal or basitemporal regions are invariably mistaken for meningioma or tuberculoma both on imaging and at surgery. The extracerebral variety could represent the rhinocerebral form wherein the paranasal sinus involvement was not detectable at initial presentation but found on MRI or on follow-up scans. The rare purely intracerebral granulomas are those in which no contiguous extension from paranasal sinuses was detectable ${ }^{[98,99]}$ and the diagnosis is often delayed until histopathology. ${ }^{[100]}$

An abscess caused by Aspergillus species of fungus contains a central area of liquefactive necrosis surrounded by a wall of hemorrhagic necrosis with acute inflammation interspersed with numerous hyphal elements. Cerebral abscess results from hematogenous seeding in immunocompromised individuals, as in HIV/AIDS, solid organ transplantation, chronic granulomatous disease and patients on corticosteroid therapy.

Cerebrovascular aspergillosis [Figures 3C, D, E] denotes a well-recognized syndrome of cerebral infarction and necrosis and/or hemorrhage without suppuration resulting from vascular invasion and

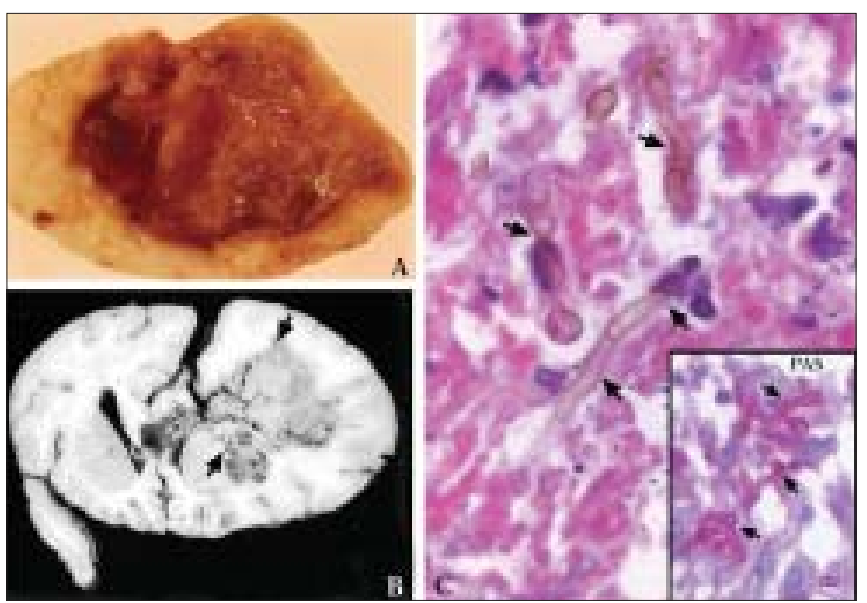

Figure 5: Chromomycotic abscess with thick organized fibrous wall and discolored luminal surface (A). Coronal slice of brain shows a large pale necrotizing infarct involving basal ganglia and frontal white matter (arrows) in a case of Cladosporium trichoides (B). Histology from necrotic material revealed characteristic pigmented, septate hyphae with disjunctures (arrows, C). PAS stain (inset) strongly labels the cell wall highlighting the constrictions (arrows). [C:HE, x600, inset: PAS, x320] 
thrombosis [Figure 3C] secondary to endovascular infection from a septic embolus or direct invasion of the vessel wall causing vasculitis. Less commonly it can follow meningitis ${ }^{[101,102]}$ or post-surgical clipping of aneurysms. ${ }^{[103]}$ The ability of Aspergillus spp. to produce enzyme elastase confers direct angioinvasive property to this fungus ${ }^{[92]}$ leading to cerebral hemorrhage or aneurysm formation [Figures 3D, E]. Inflammatory response is usually scarce, lesions occurring within the territory of affected vessels essentially in the cerebral cortex, subcortical regions and less commonly the brainstem, cerebellum and spinal cord. This form is most frequent in immunocompromised patients with hematopoietic stem cell or solid organ transplants and occasionally following corticosteroid therapy.

Although vascular invasion is common in Aspergillus lesions, true mycotic aneurysms are rare ${ }^{[104]}$ and result from direct invasion of the wall, from the luminal or adventitial side. In contrast to bacterial mycotic aneurysm, these are fusiform and involve longer and more proximal segments of intracranial vessels like basilar, middle and posterior cerebral arteries. The vessel is friable and infiltrated by hyphae. The lumen may be thrombosed leading to cerebral infarction or may serve as a source of emboli. Isolated meningitis due to Aspergillus spp. is extremely unusual, being more often a complication of other aspergillus-related lesions.

Though Aspergillus has a predilection for the CNS, spinal cord involvement has been reported very rarely. ${ }^{[105-108]}$ Most cases present as epidural mass or through involvement of thoracic vertebrae to cause cord compression and paraplegia. Upper thoracic level of the spinal cord is most commonly affected, caused by contiguous spread from lung. ${ }^{[107-109]}$

\section{Indian literature [Table 3]}

In India, sinocranial aspergillosis accounts for a significant proportion of histologically verified cases reported $^{[10,96,110-119]}$ in otherwise normal hosts in contrast to the disseminated forms that account for the majority of cases from Western countries. ${ }^{[75,120,121]}$ Young men, otherwise normal, from rural areas are most commonly affected..$^{[122-124]}$ Similarly high incidence of fungal keratitis is reported from India in apparently normal hosts. ${ }^{[125]}$ The high incidence of fungal sinusitis and keratitis is related to the spore content of pathogenic Aspergillus spp. in the environment colonizing sinuses, nasopharynx, mastoid and middle ear. In moldy environment, Aspergillus spore concentrations exceeding $12 \times 10^{6} \mathrm{~m}^{3}$ are recorded. ${ }^{[126]}$ Compromised sinus aeration, altered immune response to fungi including poor nutritional status could facilitate growth of the organism and eventual contiguous spread into cranial cavity. ${ }^{[115,127]}$ Diamond and Bennett observed that though patients appeared free from overt immunological compromise, subclinical impairment of cell-mediated immunity might be present. ${ }^{[28]}$

Despite aggressive use of amphotericin B and 5flurocytosine, the prognosis is poor as adequate tissue concentrations may not be achieved as to reach the fungi embedded deep within the tissue. ${ }^{[116,118]}$ Intracavitary instillation of amphotericin $\mathrm{B}$ has been recommended to achieve higher tissue concentrations. ${ }^{[129]}$ Radical surgical debridement is believed to be curative if the extent of

\begin{tabular}{|c|c|c|c|c|c|c|}
\hline Table 3: Aspe & sis in India & $(3)$ & 10 & & & \\
\hline $\begin{array}{l}\text { NIMHANS, } \\
\text { Bangalore } \\
(n=53) \\
1978-2006\end{array}$ & Age range (yrs) & $\begin{array}{l}\text { M:F } \\
41: 12\end{array}$ & $\begin{array}{c}\text { Predisposing factors } \\
\mathrm{n}=7(13.2 \%) \\
\text { Diabetes-5 } \\
\text { Steroids-1 } \\
\text { Tuberculosis-1 }\end{array}$ & $\begin{array}{c}\text { Clinical syndrome } \\
\text { Orbital-6 } \\
\text { Sinoorbital-8 } \\
\text { Sinus-11 } \\
\text { Sinocranial-9 } \\
\text { Parenchymal-13 }\end{array}$ & $\begin{array}{l}\text { Pathology } \\
\text { Granuloma-50 } \\
\text { Abscess-2 } \\
\text { Infarcts-1 }\end{array}$ & $\begin{array}{l}\text { Culture } \\
\mathrm{n}=16 \\
\text { A. flavus-4 } \\
\text { A. fumigatus-4 } \\
\text { Sterile-8 }\end{array}$ \\
\hline $\begin{array}{l}\text { NIMS, } \\
\text { Hyderabad } \\
(\mathrm{n}=89) \\
1988-2006\end{array}$ & 1-71 & $55: 34$ & $\begin{array}{c}\mathrm{n}=9(10.1 \%) \\
\text { Diabetes-2 } \\
\text { CSOM-1 } \\
\text { Renal transplant-1 } \\
\text { AML-1 } \\
\text { Lymphoma-1 } \\
\text { Atopic dermatitis-1 } \\
\text { SLE-1 } \\
\text { Hospital acquired-1 }\end{array}$ & $\begin{array}{c}\text { Sinocranial-47 } \\
\text { Sinoorbitocranial-9 } \\
\text { Sinoorbital-8 } \\
\text { Otocranial-5 } \\
\text { Brain abscess-1 } \\
\text { Spinal-1 } \\
\text { Cavernous sinus } \\
\text { thrombosis-2 } \\
\text { Mycotic arteritis } \\
\text { with infarcts-1 }\end{array}$ & $\begin{array}{l}\text { Granuloma-83 } \\
\text { Infarcts-4 } \\
\text { SAH-2 }\end{array}$ & $\begin{array}{l}\mathrm{n}=28 \\
\text { A. flavus-15 } \\
\text { A. fumigatus-5 } \\
\text { A. niger-2 } \\
\text { A. terreus-1 } \\
\text { Sterile-3 } \\
\text { Aspergillus-2 } \\
\text { (species not } \\
\text { identified) }\end{array}$ \\
\hline $\begin{array}{l}\text { PGIMER, } \\
\text { Chandigarh }^{[10]} \\
(n=66) \\
1980-1993\end{array}$ & $10-68$ & $2.2: 1$ & $\begin{array}{c}\mathrm{n}=9(13.6 \%) \\
\text { Steroids-2 } \\
\text { Dialysis-5 } \\
\text { Intracranial } \\
\text { surgery-2 }\end{array}$ & $\begin{array}{c}\text { Rhinocerebral I-22 } \\
\text { Intracerebral-8 } \\
\text { Subarachnoid } \\
\text { Hemorrhage-2 }\end{array}$ & $\begin{array}{c}\text { Granulomas-32 } \\
\text { Non granulomatous-14 }\end{array}$ & Not available \\
\hline $\begin{array}{l}\text { KEM, } \\
\text { Mumbai[118] } \\
(n=18) \\
1967-2005\end{array}$ & $20-58$ & $12: 6$ & $\begin{array}{c}\mathrm{n}=5(27.7 \%) \\
\text { Diabetes-3 } \\
\text { HIV-2 }\end{array}$ & $\begin{array}{l}\text { Cavernous sinus:4 } \\
\text { Intracerebral-14 }\end{array}$ & $\begin{array}{l}\text { Granulomas-10 } \\
\text { Granuloma } \\
\text { +infarction-1 } \\
\text { Infarction-1 }\end{array}$ & Not available \\
\hline
\end{tabular}


surgical resection extends into the uninvolved tissue and can reduce mortality from $64 \%$ to $39 \% \cdot{ }^{[99,130,131]}$ The stress of surgery and steroid therapy to control cerebral edema in the immediate postoperative phase could be contributory factors in the fungal growth.

True mycotic aneurysms caused by direct invasion of Aspergillus hyphae into vessel wall and rupture causing subarachnoid hemorrhage is rarely reported in the Indian literature. ${ }^{[132,133]}$ The possibility of iatrogenic fungal meningitis with fungi being introduced into the subarachnoid space during spinal anesthesia is suggested in some of the cases. ${ }^{[133]}$

Other forms of CNS aspergillosis including invasive form, ${ }^{[134]}$ brain abscess ${ }^{[111,135]}$ are reported rarely from India. Uppin et al. in this same issue report rare occurrence of pale infarcts resulting from angioinvasion and thrombosis. A single case involving thoracic vertebra and forming a paraspinal mass by contiguous extension from pulmonary aspergillosis is reported from Mumbai $^{[136]}$ and two other cases from NIMHANS ${ }^{[111]}$ causing spinal cord compression.

In a large series of 456 samples of Aspergillus spp. cultured from clinical samples, A. flavus (46.93\%) was the most common isolate followed by $A$. fumigatus $(37.72 \%)$ and A. niger (15.35\%). A. fumigatus was the predominant species isolated from the blood and respiratory tract specimens and $A$. flavus from nasal polyps whereas $A$. niger predominated in nail specimens. ${ }^{[137]}$

The high prevalence of A. flavus in nasal polyps could explain the high incidence of the sinocranial form of aspergillosis from India. ${ }^{[16]}$

\section{Zygomycosis (Mucormycosis)}

Zygomycosis is a worldwide polymorphic disease caused by the fungi of the class zygomycetes-order mucorales and entomophthorales. Members of the order mucorales grow profusely on decaying vegetables, seeds, fruits, compost piles, animal excreta and bread rich in carbohydrates. The disease is an opportunistic infection and the distribution of the various clinical forms is based on the predisposing factor rather than on age, gender, race or geography. Zygomycosis is caused by several genera belonging to the family Mucoraceas such as Rhizopus, Mucor and Absidia. Rhizopus is the offending organism in 95\% of cases (Rhizopus arrhizus and Rhizopus oryzae). The fungus in culture consists of broad, branching, non-septate hyphae measuring 6-15 $\mu \mathrm{m}$ in diameter and up to $200 \mu \mathrm{m}$ in length, from the base of which root-like structures (rhizoids) grow. From the rhizoids, sprouts (sporangiospores) bearing asexual fruiting heads (sporangia) develop, which are frequently airborne. Some of the major predisposing factors to zygomycosis are: diabetic ketoacidosis, hematological malignancies, neutropenia, immunosuppressive medication, renal failure, bone marrow or solid organ transplantation, septicemia, trauma, burns, starvation, IV drug abuse, premature babies and Hepatitis A - a feature common to the majority of these being high tissue catabolism and ketoacidosis. Rarely, nosocomial infections from contaminated elastoplast bandages ${ }^{[138]}$ and catheters ${ }^{[139]}$ are recorded.

Clinically, the manifestations of zygomycosis are protean but can be classified into six distinct clinical syndromes: rhino-orbito-cerebral, pulmonary, gastrointestinal, cutaneous, disseminated and miscellaneous. ${ }^{[140]}$

Unlike most other mycoses in which cerebral involvement is secondary to a primary focus in the lung (aerosol entry), this mycosis establishes most frequently from an infection of the facial skin, nasal and paranasal sinus mucosa or nasopharynx and spreads to the arteries in the rhino-maxillary-orbital territory and the internal carotid artery with eventual thrombosis. The basifrontal area is involved by direct venous invasion through the orbital plate and cavernous sinus [Figure 4A]. Brain involvement results from hematogenous dissemination resulting in venous thrombosis and hemorrhagic lesions, involving diencephalic areas, usually sparing the infratentorial structures [Figure $4 \mathrm{~B}$. The main pathological feature of acute invasive cerebral zygomycosis is invasion of the vessels leading to thrombosis and necrosis of the vessel wall, [Figures 4C, D] the fungus coursing through the lumen. In the chronic invasive form of the disease in immunocompetent individuals, chronic inflammatory exudate is seen admixed with polymorphs and eosinophils as small microabscesses surrounded by epitheloid and giant cells. The hyphal elements coursing through the tissue are surrounded by a eosinophilic sleeve encrusted with polymorphs (Splendore-Hoeppli phenomenon). The fungus is essentially extravascular after it reaches the brain through larger veins or arteries, resulting in hemorrhagic infarcts with cavitation involving the white matter or diencephalic nuclei. Although these fungi have been considered opportunistic, the cerebral form of the disease has been recorded in previously healthy individuals. ${ }^{[141]}$ In diabetic ketoacidosis there is substantially reduced binding of iron to transferrin, leading to freely available iron promoting the growth of Rhizopus oryzae. ${ }^{[142]}$ However, the mechanism of susceptibility to zygomycosis in patients with other predisposing factors is not clear though enhanced metabolism, acidosis and neoglucogenesis could be contributing. Though the fungus readily invades the vessel wall, no definite virulence factor has been identified.

Zygomycosis fungi, though can be cultured easily on routine mycological media, are often difficult to recover from clinical samples, as during biopsy procedure or processing in the laboratory the hyphal elements get 
damaged and are rendered non-viable. No standard rapid serological method for diagnosis of zygomycosis is available, as unlike other fungi, zygomycosis does not contain D-glucan (DG) cell wall component and is antigenically relatively non-reactive. However, specific antisera produced against hyphal forms are effective in reducing pathology in mice with zygomycosis, suggesting a protective role of humoral response. Interestingly, reports of co-infection with two fungal pathogens along with zygomycete are reported in the literature, indicating pathological succession of the fungal pathogens in the host's necrotizing tissue and emergence of synergistic infections influencing the clinical course. ${ }^{[143]}$ Although prognosis is considered poor, aggressive surgical debridement and antifungal therapy have increased the survival.

\section{Indian literature [Table 4]}

The largest series of 129 cases of zygomycosis from a single center from India is reported from Chandigarh ${ }^{[144]}$ followed by Nizam's Institute of Medical Sciences (NIMS), Hyderabad and NIMHANS, Bangalore. ${ }^{[145,146]}$ Rhino-orbito-cerebral type was the most common presentation, uncontrolled diabetes mellitus (50\%) being the significant risk factor in the rhinocerebral form. Rhizopus arrhizus was the most common isolate

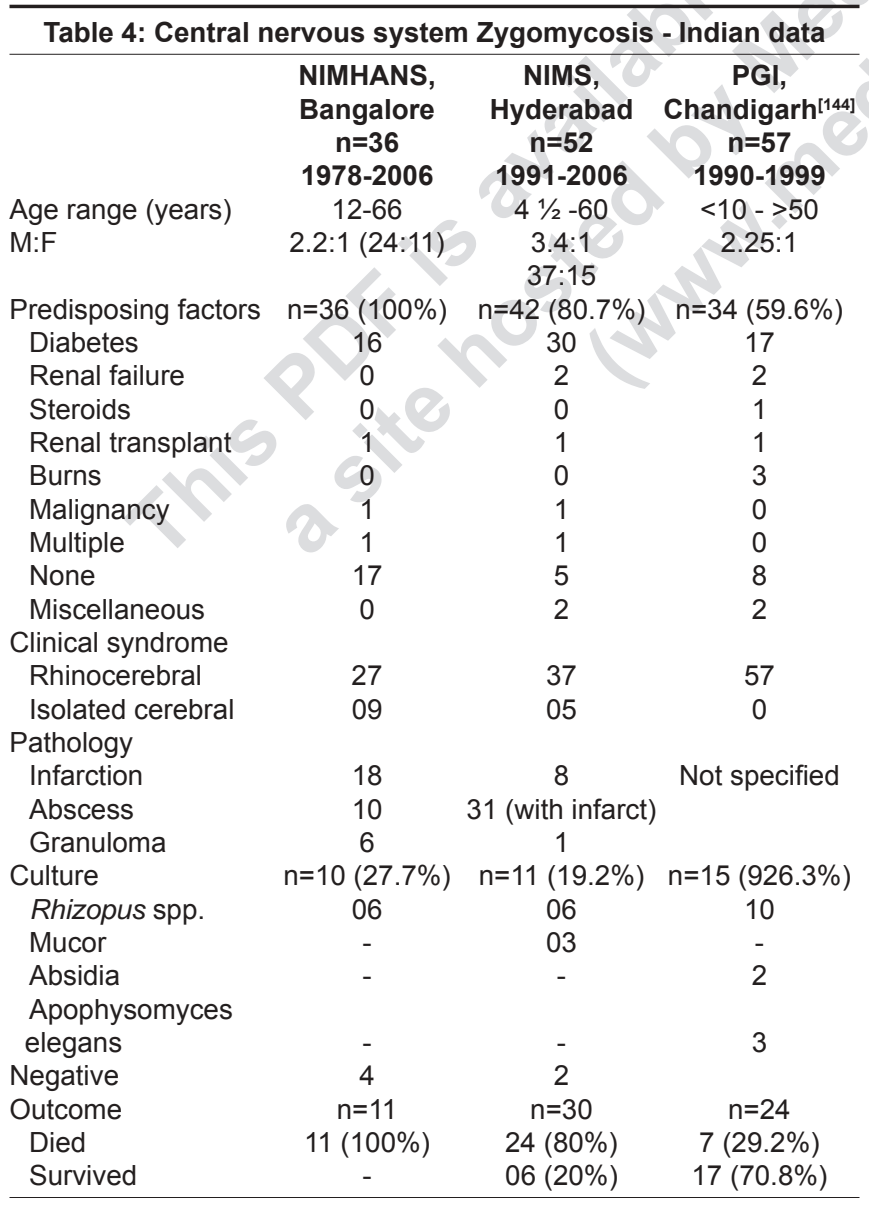

followed by Apophysomyces elegans. A. elegans has been reported only rarely from other centers. ${ }^{[147,148]}$ Infection of cutaneous and subcutaneous tissue with local invasion to neighboring structures is by far the most common by A. elegans. Weinberg et al. suggested higher isolation of A. elegans from patients living in warm climates as the fungus is a thermophile. ${ }^{[147]}$

High survival rate of $70.8 \%$ was reported by Chakrabarti et al. ${ }^{[144]}$ in the rhino-orbito-cerebral form of zygomycosis following timely medical and/or surgical intervention.

\section{Pheohyphomycosis}

This is a term used to describe infections caused by pigmented fungi that contain melanin in their cell walls. These incite a variety of clinical syndromes ranging from subcutaneous nodules to brain abscesses and disseminated disease. The unique feature of this fungal infection is that it causes pathology in immunocompetent individuals. Most species are considered as opportunists though some may be true pathogens.

Agents of pheohyphomycosis that include the genera Cladosporium, Hormodendrum and Phialophora are common saprophytes found in soil and decaying vegetation. They cause a chronic cutaneous mycosis in adult males involving predominantly the lower extremities in agricultural and forest workers walking barefoot and are exceptionally rare in children. Cladophialophora bantiana is the most common species isolated. Interestingly, virulent infections due to Ramichloridium mackenziei have only been seen in the Middle East region and there are no documented survivors till date. ${ }^{[149]}$

Cerebral pheohyphomycosis arises from an extracranial infected site and spreads to the brain hematogenously. Revankar et al. ${ }^{[149]}$ in their extensive review of 101 cases of primary CNS pheohyphomycosis found that except for one case with contralateral sinusitis, no patient had sinusitis or otitis making local extension unlikely. The hematogenous route is the most likely source of CNS infection from a primary subclinical pulmonary focus or cutaneous lesions. An intriguing possibility of neurotropism is that of metabolic tropism to melanin that may be responsible for CNS localization. Receptors that recognize melanin or its biochemical byproducts could allow these fungi to cross the blood-brain barrier and enter the brain parenchyma. However, human melanin (derived from tyrosine) and fungal melanin (mostly derived from acetate) are different biochemically although they share the same physicochemical properties. This notion is therefore speculative as it does not explain why so few are infected when many more individuals are exposed to this mycosis. Melanin is a known virulence factor in many fungi and has been extensively studied in Cryptococcus neoformans and Wangiella dermatiditis. ${ }^{[150-157]}$ It is believed to confer 
protection from scavenging free radicals produced by phagocytic cells in their oxidative outburst that would normally kill organisms. ${ }^{[153]}$ In addition, melanin binds to hydrolytic enzymes thereby preventing their action on the plasma membrane. These multiple functions of melanin, may help explain the pathogenic potential of some dematiaceous fungi, even in immunocompetent hosts.

An unusual manifestation of brain involvement is abscess formation without meningitis. ${ }^{[158,159]}$ Alternatively, meningitis may be the sole manifestation. ${ }^{[160]}$ The CNS may be the only site of infection as in other mycoses, ${ }^{[161]}$ the frontal lobe being the most commonly involved site. Single or multiple abscesses may enlarge to produce leptomeningitis or ventriculitis. The characteristic brown color of the mycelium can sometimes be recognized macroscopically. ${ }^{[162]}$

Histologically the lesions are primarily intraparenchymal abscesses. They are larger than the microabscesses caused by pseudohyphae of Candida spp. Granulomatous response has also been described, the fungus located within the giant cells walled in by fibrosis and reactive gliosis. The pigmented fungal hyphae are slender (2-3 $\mu \mathrm{m}$ thick) with constrictions occurring at every 3-15 $\mu \mathrm{m}$ interval. Sometimes the pigment may not be apparent in stained sections with PAS and methenamine silver. The melanin-specific Masson-Fontana stain has been used to confirm the presence of dematiaceous hyphae in tissues.

Clinical management of these primary CNS pheohyphomycoses is problematic due to their poor response to standard antifungals and mortality rates are high regardless of immune status of the host. Treatment with a combination of Amphotericin B, 5-flucytosine and itraconazole was associated with improved survival.

\section{Indian data [Table 4]}

Pheohyphomycosis appears uncommon in India. The largest number of cases is reported from NIMHANS (14 cases, 7.65\%). ${ }^{[163]}$ Most presented with cerebral abscesses involving the frontal lobes [Figure 5A], although rare presentation with cerebral infarction [Figure 5B] was also seen. Histology revealed characteristic pigmented hyphal forms with constrictions in the necrotic wall of the abscess or the infarcted tissue [Figure 5C]. Cladosporium trichoides was the most common isolate. Outcome was uniformly fatal where details were available with no survivors documented [Table 5]. Four cases are reported from NIMS, Hyderabad (unpublished data) and two cases each from the All India Institute of Medical Sciences, New Delhi and Christian Medical College, Vellore. The first report of this clinical entity from India was by Bagchi et al. ${ }^{[164]}$ and the first culture-proven case was by Dastur et al. ${ }^{[165]}$ This was followed by sporadic reports from other centers with no predilection for race or geographic location. ${ }^{[166-169]}$ A cerebral abscess caused
Table 5: Clinicopathological features of Pheohyphomycosis cases reported from NIMHANS, Bangalore (1978-2006)
No. of cases

Age range (years)

Clinical presentation

Duration of illness

Pathology

Site

Predisposing factors

Culture

Outcome
14

3-67 years

Focal neurological deficits-9

Seizures-4

Fever-4

Raised intracranial tension-5

Psychiatric symptoms-2

Altered sensorium-2

Meningism-2

1-6 months

Granuloma-9

Abscess-3 (Fonsecaea pedrosoi -1)

Infarction-2

Frontal-5

Parietal-1

Frontoparietal-1

Frontotemporoparietal-2

Temporoparietal-2

Corpus callosum -1

Mutilple-1

Mill worker-1

Alcholoic-1

Rest-nil

Cladosporium trichoides-6

Fonsecaea pedrosoi-1

Not available-10

Expired-5

Not available-9 by Fonsecaea pedrosoi, a rare chromomycotic infection was reported from NIMHANS, Bangalore. ${ }^{[170]}$ Most infections of pheohyphomycosis occurred in the second and third decade, the youngest case documented was in a six-day-old neonate. ${ }^{[171]}$ Almost all cases involved immunocompetent hosts except for an occasional report in a renal transplant recipient. ${ }^{[172]}$ High mortality was seen in almost all reported cases mainly due to delay in surgical resection and treatment with less effective antifungal agents like amphotericin B. Vyas et al. report survival following early and complete surgical resection with flucytosine therapy. ${ }^{[173]}$

\section{Penicilliosis marnefei}

Penicilliosis marneffei is a facultative, intracellular pathogen, the only thermally dimorphic fungus, growing as mould at $25^{\circ} \mathrm{C}$ on Saboraud's Dextrose agar and converts to yeast form at $37^{\circ} \mathrm{C}$ on enriched medium. The unique feature of the fungus is the presence of a soluble red pigment diffusing into the agar. The cell wall has mannoprotein which is antigenic. No definite virulence determinant of this fungus has been identified.

This fungus is the third most common opportunistic infection in HIV infected patients of South East Asia, following pulmonary tuberculosis and cryptococcosis. ${ }^{[174,175]}$ It causes progressive infection in both immunocompetent and immunocompromised hosts. The organism invades the reticuloendothelial system, intracellular and extracellular basophilic, 
elliptical yeast forms with a clear central septation seen in macrophages. Differentiation between Peniciliosis marneffei and $\mathrm{H}$. capsulatum is important because both are intracellular pathogens. Histopathologically, penicilliosis causes granulomatous reaction in immunocompetent patients. In immunosuppressed individuals it causes necrotizing abscesses with neutrophils and fibrin and macrophages engorged with proliferating yeast cells in tissues, heralding signs of disseminated infection. The organism can be isolated from blood and the CSF, suggesting involvement of the nervous system. The clinical symptoms are nonspecific and resemble closely other fungal infections like histoplasmosis and cryptococcosis in HIV infected patients.

\section{Indian data}

This fungal infection is recognized in HIV infected individuals from the northeastern state of India, Manipur and the majority of the patients were IV drug abusers sharing unsterilized needles but not a single pathologically confirmed brain lesion has been recorded from that state. ${ }^{[176,177]}$ However, in the literature, successful isolation of the fungus from meninges has been reported. ${ }^{[178]}$ In a follow-up study of 36 cases of Penicilliosis marneffei from Jawaharlal Nehru Medical College Hospital, Imphal, Manipur, other coexisting opportunistic infections like pulmonary/extrapulmonary tuberculosis, oral candidiasis, cryptococcal meningitis, mucocutaneous Herpes simplex and multidermatomal Herpes zoster infections have been reported. Cellmediated immunity plays a central role in the host defense mechanism against this infection. Response to itraconzole and fluconazole was found to be good.

\section{Other Uncommon Dimorphic Fungi Involving the CNS}

These are geographically restricted mycoses, corresponding to the areas in the world where warm temperature and dry conditions exist. The fungi belonging to this group are Coccidioides immitis, Paracoccidioides braziliensis, Histoplasma capsulatum, Sporotrichum schenkii, Blastomyces dermatitides. The organisms live in the soil and in vegetation. These fungi penetrate the oral, pharyngeal and nasal mucosa by ingestion or inhalation causing focal lesions and then are carried hematogenously to other viscera like lungs and reticuloendothelial organs and rarely to CNS. The pulmonary and lymph node lesions can be self-limiting, the primary focus undergoing calcification. The central nervous system involvement usually becomes apparent one to three months after the primary infection. The disseminated disease develops in less than $0.2 \%$ of cases $^{[179]}$ and occurs more often in pregnant, diabetic and immunocompromised individuals.

These fungi manifest chiefly as acute, subacute or chronic symptomatic meningitis or with meningoencephalitic symptoms. Blockage of the CSF pathway may result in hydrocephalus. Extensive spinal meningitis may cause adhesive arachnoiditis and spinal cord compression. The pathological changes observed on gross, microscopic examination and changes in the CSF closely resemble those of tuberculous meningitis. The organisms can be located in the histiocytes and giant cells by methenamine silver stain. However, the lesions may be overlooked, being mistaken for cryptococcal or mycobacterial infection in view of the close similarity in pathogenesis and pathology. Awareness of the geographic pathology, culture or antigenic characterization are the key to recognition.

Pseudoallescheria boydii infection presenting as a mycetoma is a very rare cerebral mycosis. The organisms are present in the soil and water as thin septate hyphae. When the organism infects the nervous system, it causes meningoencephalitis with microabscesses and rarely, mass lesions and hemorrhagic infarcts. With persistence of the infection, the suppurative lesion may become granulomatous in nature. Histological examination not only establishes the diagnosis but also allows specific identification of the causative agent.

Madurella mycetoma usually involves subcutaneous tissues of the lower extremities and involvement of CNS and cranial bones is extremely rare and sporadic cases are reported from India..$^{[9,180]}$ The organisms reach the brain following local trauma. The black grains of Madurella mycetomatis found in the midst of neutrophilic abscesses contain uniform rust brown cement and hyphae with expanded terminal cells. Surgical management and amphotericin B are found useful in mycetoma of lower limbs.

\section{Therapeutic Rationale of CNS Fungal Infections}

Parallel to the increase in the incidence of opportunistic fungal infections, especially following immunosuppressive states like post transplantation, and metabolic derangement like diabetes and HIV/ AIDS, there has been introduction of new antifungal agents to combat the disease. Though both superficial and systemic fungal infections elicit cell-dependent immune reaction, the host immunity is not strong enough to eradicate and the fungus can remain dormant for long periods, waiting for an opportune moment to get reactivated. The relative uniqueness of the fungal cell wall antigens in contrast to the human host is exploited to develop antifungal pharmacological agents. Both yeast and hyphal forms, because of their size and thick cell wall can reach the nervous system only 
through circulation. Various proteases secreted by the fungi help in reaching a conducive nidus in the brain, breaching the vasculature. The presence of glucose and serum proteins and absence of complement system and inflammatory cells facilitate the growth of the fungi once they reach the CSF pathway and brain parenchyma. The recognition of these characteristics formed the bedrock for developing antifungal agents and understanding the mechanism of antifungal therapy at the bedside.

Conventional amphotercin B, a polyene macrolide heptane, binds to the ergosterol in the cell membrane causing direct membrane toxicity, partly by oxidative damage. Though human cell membrane lacks ergosterol, amphotericin B, a polyene binds to the cell membrane cholesterol of the mammalian cells, resulting in toxicity to metabolically active cells in the liver and kidney. Amphotericin B is unstable when exposed to heat, light and acidic $\mathrm{pH}$. Lipid formations of the drug increase the efficiency and reduce toxicity, while treating deep mycosis.

The azole group of drugs inhibit the fungal cytochrome p450-dependent enzymes, thereby impairing ergosterol synthesis. Ketoconazole is orally effective but penetrates CSF poorly. Itraconazole and fluconazole are active orally and less toxic, because of their more specific binding to fungal cell wall cytochrome p450. Fluconazole, because of relatively small molecular size is watersoluble, minimally protein-binding, excreted in urine as an active drug, penetrates well into the CSF and has prolonged half life (25h in humans), thus is effective for CNS mycosis caused by Cryptococcus, Candida and hyphal forms.

5-Flurocytosine, a competitive antimetabolite for uracil in the synthesis of yeast RNA interfering with thymidilate synthetase, is a water-soluble, stable fungi static compound, used orally. It works synergistically with amphotericin B, in the treatment of cryptococcal meningitis. As the human cells lack the enzyme system to synthesize fungal cell wall glycans and chitin, drugs like Echinocandin and Nikkomycin are developed exploiting this biochemical selectivity and are entering the clinical trails. Though the antifungal therapy is used extensively and favorable clinical response is noted, how it alters the host tissue response is unclear, especially following long-term therapy.

\section{Epilogue}

Despite significant advances in taxonomy, cultural characters and molecular biology of fungi, critical gaps still remain in understanding their pathobiology. Important questions like how the fungi survive in the host cell, particularly in granulomas, how long and where they persist during sub-clinical infections and how they exploit the host defenses for their survival and pathogenicity remain unanswered. The newly emerging branch of comparative genomics will provide insight into the synergistic and antagonistic influence of fungi and bacteria on their respective growth in the "microbial ecosystem" in the host causing manifest diseases. Many of the fungi retain their pathogenic potential and virulence in diverse animal hosts without this being a requirement for replication and survival. Passage of a virulent strain of $\mathrm{H}$. capsulatum in the presence of soil ameba (A. castellani) results in selection of variants that are pathogenic in mice indicating that the virulence in the pathogen can be amplified by interaction with an amoeboid host. ${ }^{[181]}$ The replication and acquisition of the polysaccharide capsule by C. neoformans in the amoeba is a feature similar to interaction between macrophages and ingested yeast forms of fungi. Similarly, nonpathogenic cryptococci are killed by nematodes while wild strain of $C$. neoformans is lethal to the worms. ${ }^{[182]}$ It is plausible that in tropical developing countries the intestinal nematodes may be involved in modulating the survival and virulence of systemic fungi. The study of the interaction between the fungi and their potential host in the environment is a rich area of investigation to explore the fundamental question related to pathogenesis in clinical medicine.

\section{Acknowledgments}

We thank the clinicians, the microbiologists and resident staff of different centers for their assistance in establishing the diagnosis. Patient secretarial assistance provided by Mrs. Kanakalakshmi, data retrieval by Ms. Neema Susan Monteiro and Mr. Shivaji and photographic work by Mr. K. Manjunath are gratefully acknowledged.

\section{References}

1. Kahn FW, Hones JM, England DM. The role of bronchoalveolar lavage in the diagnosis of invasive pulmonary aspergillosis. Am J Clin Pathol 1986,86:518-23.

2. Delamater ED, Benham RW. Experimental studies with dermatophytes II. Immunity and hypersensitivity produced in laboratory animals. J Invest Dermatol 1939;1:469-88.

3. Friedman L, Derbes V.J. The question of immunity in ringworm infections. Ann NY Acad Sci 1960;89:179-83.

4. Grappel SF, Bishop CT, Blank F. Immunology of dermatophytes and dermatophytosis. Bact Rev 1974;38:222-50.

5. Rippon JW. Medical mycology-The pathogenic fungi and pathogenic actinomycetes. WB Saunders Co: USA; 1982. p. 154-248.

6. Cox RA, Arnold DR. Immunoglobulin E in Coccidiodomycosis. J Immunol 1979;123:194-200.

7. Graybill JR, Mitchell L. Host defense in Cryptococcosis. III. In vivo alteration of the host immunity. Mycopathologia 1979;69:171-8.

8. Chitravel V, Sundararaj T, Subramanian S, Kumaresan M, Kunjithapadam S. Cell mediated immune response in human cases of rhinosporidiosis. Sabouraudia 1981;19:135-42.

9. Sundaram C, Umabala P, Laxmi V, Purohit AK, Prasad VS, Panigrahi M, et al. Pathology of fungal infections of the central nervous system: 17 years experience from South India. Histopathology 2006;49:396-405.

10. Sharma BS, Khosla VK, Kak VK, Banerjee AK, Vasishtha RK, Prasad KS, et al. Intracranial fungal granuloma. Surg Neurol 1997;47:48997 . 
11. Mohr JA, Long H, McKown BA, Muchmore HG. In vitro susceptibility of Cryptococcus neoformans to steroids. Sabouradia 1972;10:171-2.

12. Levitz SM. The ecology of Cryptococcus neoformans and the epidemiology of cryptococcosis. Rev Infect Dis 1991;13:1163-9.

13. Mitchell DH, Sorrell TC, Allworth AM, Heath CH, McGregror $\mathrm{AR}$, Papanaoum K, et al. Cryptococcal disease of the CNS in immunocompetent hosts: Influence of cryptococcal variety on clinical manifestations and outcome. Clin Infect Dis 1995;20:611-6.

14. Chakrabarti A, Jatana M, Kumar P, Chatha L, Kaushal A, Padhye A. Isolation of Cryptococcus neoformans var. gattii from Eucalyptus camaldulensis in India. J Clin Microbiol 1977;35:3340-2.

15. Lazera MS, Pires FD, Camillo-Coura L, Nishikawa MM, Beserra CC, Trilles L, et al. Natural habitat of Cryptococcus neoformans var. neoformans in decaying wood forming hollows in living trees. J Med Vet Mycol 1996;34:127-31.

16. Meyer W, Marszewska K, Amirmostofian M, Igreja RP, Hardtke C, Methling K, et al. Molecular typing of global isolates of Cryptococcus neoformans var. neoformans by PCR-fingerprinting and RAPD-A pilot study to standardize techniques on which to base a detailed epidemiological survey. Electrophoresis 1999;20:1790-9.

17. Franzot SP, Hamdan JS, Currie BP, Casadevall A. Molecular epidemiology of Cryptococcus neoformans in Brazil and the United States: Evidence for both Local Genetic differences and Global Population structure. J Clin Microbiol 1997;35:2243-51.

18. Hussain S, Wagener MM, Singh N. Cryptococcus neoformans infection in organ transplant recipients: Variables influencing clinical characteristies and outcome. Emerg Infect Dis 2001;7:375-81.

19. Kappe R, Muller J. Rapid clearance of Candida albicans mannan antigens by liver and spleen in contrast to prolonged circulation of Cryptococcus neoformans antigens. J Clin Microbiol 1991;29:1665-9.

20. Heelan JS, Corpus A, Kessimian N. False positive reactions in latex agglutination test for Cryptococcus neoformans antigen. J Clin Microbiol 1991;29:1260-1.

21. Hamilton AJ, Jeavons L, Hobby P, Hay RJ. A 34 to 38kDa Cryptococcus neoformans glycoprotein produced as an exoantigen bearing a glycosylated species-specific epitope. Infect Immun 1992;60:143-9.

22. Hamilton AJ, Goodley J. Purification of the $150 \mathrm{kDa}$ exoantigen of Cryptococcus neoformans and its recognition by immune sera. J Clin Microbiol 1993;31:335-9.

23. Banerjee U. Progress in diagnosis of opportunistic infections in HIV/ AIDS. Indian J Med Res 2005;121:395-406.

24. Rajendran P, Balakrishnan P, Anand Rao U, Thyagarajan SP, Hitcheock C, Kidd S, et al. Molecudlar epidemiology of clinical and environmental isolates of Cryptococcus neoformans from India. In: Proceedings of the International symposium on "Mycotic infections in the $21^{\text {st }}$ century". Venugopal PV, Venugopal TV, editors. Medical Council of India: New Delhi; 2002. p. 55-67.

25. Fessler RD, Sobel J, Guyot L, Crane R, Vazguez J, Szuba M, et al. Management of elevated intracranial pressure in patients with Cryptococeal meningitis. J Acquir Immune Defic Syndr Hum Retrovirol $1998 ; 17: 137-42$.

26. Wright D, Schneider A, Berger JR. Central nervous system opportunistic infections. Neuroimag Clin N Am 1997;7:513-25.

27. Wadia RS, Pujari SN, Kothari S, Udhar M, Kulkarni S, Bhagat S, et al. Neurological manifestations of HIV disease. J Assoc Physicians India 2001;49:343-8.

28. Shankar SK, Mahadevan A, Satishchandra P, Udaykumar R, Yasha TC, Santosh V, et al. Neuropathology of HIV/AIDS with an overview of the Indian scene. Indian J Medical Res 2005;121:468-88.

29. Pancharoen C, Chindamporn A, Thisyakorn U. Childhood cryptococcosis: An increasing problem in the era of AIDS. J Med Assoc Thai 2001;84: S86-90.

30. Radhakrishnan VV, Mathai A, Shanmugham J, Mathews GJ. The role of hyaluronidase in experimental Cryptococcal infections. Surg Neurol $1982 ; 17: 239-44$.

31. Saag MS, Graybill RJ, Larsen RA, Pappas PG, Perfect JR, Powderly WG, et al. Practice guidelines for the management of cryptococcal disease. Infectious Diseases Society of America. Clin Infect Dis 2000;30:710-8.

32. Lee SC, Casadevall A, Dickson DW. Immunohistochemical localization of capsular polysaccharide antigen in the central nervous system cells in Cryptococcal meningoencephalitis. Am J Pathol 1996;148:1267-74.

33. Khanna N, Chandramuki A, Desai A, Ravi V. Cryptococcal infection of the central nervous system: An analysis of predisposing factors, laboratory findings and outcome in patients from South India with special reference to HIV infection. J Med Microbiol 1996;45:376-9.

34. Tjia TL, Yeow YK, Tan CB. Cryptococeal meningitis. J Neurol Neurosurg Psychiatry 1985;48:853-8.

35. Leite AG, Vidal JE, Bonasser Filho F, Nogueira RS, Oliveira AC. Cerebral infarction related to cryptococcal meningitis in an HIV-infected patient: Case report and literature review. Braz J Infect Dis 2004;8:1759.

36. Goel D, Kalita J, Misra UK. Basilar artery occlusion in Cryptococcal meningitis. Neurol India 1999;47:245-6.

37. Satishchandra P, Nalini A, Gourie-Devi M, Khanna N, Santosh V, Ravi $\mathrm{V}$, et al. Profile of neurological disorders associated with HIV/AIDS from Bangalore, South India (1986-1996). Indian J Med Res 2000;111:1423.

38. Aquinas SR, Tarey SD, Ravindran GD, Nagamani D, Ross C. Cryptococeal meningitis in AIDS - need for early diagnosis. J Assoc Physicians India 1996;44:178-80.

39. Kumaraswamy N, Solomon P, Flaningan TP, Hemalatha R, Thyagarajan SP, Mayer KH. Natural history of human immunodeficiency virus disease in southern India. Clin Infect Dis 2003;36:79-85

40. Vajpayee M, Konswal S, Sethi P, Wig N. Spectrum of opportunistic infections and profiles of CD4 cell counts among AIDS patients in Northern India. Infection 2003;31:336-40.

41. Lanjewar DN, Jain PP, Shetty CR. Profile of central nervous system pathology in patients with AIDS: An autopsy study from India. AIDS 1998;12:309-13.

42. Sharma SK, Kadhiran T, Banga A, Goyal T, Bhatia I, Saha PK. Spectrum of clinical disease in a series of 135 hospitalized HIV-infected patients from North India. BMC Infect Dis 2004;4:52.

43. Satpute MG, Telang NV, Litake GM, Niphadkar KB, Joshi SG. Prevalence of cryptococcal meningitis at a tertiary care hospital in Western India (1996-2005). J Med Microbiol 2006;55:1301-2.

44. Banerjee U, Dutta K, Majumdar T, Gupta K. Cryptococeosis in India: Awakening of a giant? Med Mycol 2001;39:51-67.

45. Madan M, Ranjitham M, Chandrasekharan S, Sudhakar P. Cryptococcal meningitis in immunocompetent individuals. J Assoc Physicians India 1999;47:933-4.

46. Sanchetee P. Cryptococcal meningitis in immunocompetent patients. J Assoc Physicians India 1998;46:617-9.

47. Prasad KN, Agarwal J, Nag VL, Verma AK, Dixit AK, Ayyagari A. Cryptococeal infection in patients with clinically diagnosed meningitis in a tertiary care center. Neurol India 2003;51:364-6

48. Nadkarni TD, Menon RK, Desai KI, Goel A. A solitary cryptococcal granuloma in an immunocompetent host. Neurol India 2005;53:3657.

49. Jaiswal SP, Hemwani N, Sharma N, Athale S, Chitnis DS. Prevalence of fungal meningitis among HIV positive and negative subjects in Indore (MP state). Indian J Med Sci 2002;56:325-9.

50. Pandit L, Agarwal A, Shenoy S, Karnath G. Cryptococcal meningitis and pulmonary crytpococeosis in a non-HIV infected patient. Eur $\mathrm{J}$ Gen Med 2006;3:80-2.

51. Malhotra P, Chauhan S, Bhatt P, Varma N, Chakrabarti A, Kumari S, et al. Crytpococcal meninigitis in acute lymphoblastic leukemia. J Assoc Physicians India 2004; 52:831-2.

52. Banerjee U, Dutta K, Casadavell A. Serotype distribution of Cryptococcus neoformans in patients in tertiary care center in India. Med Mycol 2004:42:181-6.

53. Kwon-Chung KJ, Bennett JE. Epidemiological differences between the two varieties of Cryptococcus neoformans. Am J Epidemiol 1984;120:123-30.

54. Banerjee U, Dutta K, Diwedi M, Sethi S. Cryptococcosis due to C neoformans var gattii: A short review and Indian clinical scenario. Nat $J$ Infect Dis 2001;2:32-6.

55. Marques SA, Robles AM, Tortorano AM, Tuculet MA, Negroni R, Mendes RP. Mycoses associated with AIDS in the Third World. Med Mycol 2000;38:269-79. 
56. Singh A, Bairy I, Shivananda PG. Spectrum of opportunistic infections in AIDS. Indian J Med Sci 2003;57:16-21.

57. Lattif AA, Banerjee U, Prasad R, Biswas A, Wig N, Sharma N, et al. Susceptibility pattern and molecular type of species-specific Candida in oropharyngeal lesions of Indian human immunodeficiency virus-positive patients. J Clin Microbiol 2004;42:1260-2.

58. Badarinarayanan G, Gowrisankar R, Muthulakshmi K. Esophageal candidiasis in non-immune suppressed patients in a semi-urban town, southern India. Mycopathologia 2000;149:1-4.

59. Gutierrez J, Morales P, Gonzalez MA, Quindos G. Candi da dubliniensis, a new fungal pathogen. J Basic Microbiol 2002;42:207-27.

60. Abi-Said D, Anaissie E, Uzun O, Raad I, Pinzcowski H, Vartivarian S. The epidemiology of hematogenous candidiasis caused by different Candida species. Clin Infect Dis 1997;24:1122-8.

61. Goswami R, Dadhwal V, Tejaswi S, Datta K, Paul A, Haricharan RN, et al. Species-specific prevalence of vaginal candidiasis among patients with diabetes mellitus and its relation to their glycaemic status. J Infect 2000;41:162-6.

62. Chimelli L, Mahler-Aranjo MB. Fungal infections. Brain Pathol 1997;7:613-27.

63. Scaravilli F. Parasitic and fungal infections. In: Greenfield's Neuropathology, Adams JH, Duchen LW, editors. $5^{\text {th }}$ ed. Edward Arnold: London; p. 400-46.

64. Nguyen MH, Yu VL. Meningitis caused by Candida species: An emerging: problem in neurosurgical patients. Clin Infect Dis 1995;21:323-7.

65. Chiou CC, Wong TT, Lin HH, Hwang B, Tang RB, Wu KG, et al. Fungal infection of ventriculoperitoneal shunts in children. Clin Infect Dis 1994;19:1049-53.

66. Sanchez-Portocarrero J, Martin-Rabadan P, Saldana CJ, Perez-Cecilia E. Candida cerebrospinal fluid shunt infection. Report of two new cases and review of the literature. Diagn Microbiol Infect Dis 1994;20:3340 .

67. Jafari HS, Saez-Llorens X, Grimprel E, Argyle JC, Olsen KD, McCracken GH Jr. Characteristies of experimental Candida albicans infection of the central nervous system in rabbits. J Infect Dis 1991;164:389-95.

68. Kirkpatrick JB. Neurologic infections due to bacteria, fungi and parasites. In: Textbook of Neuropathology. Davis RL, Robertson DM, editors. $3^{\text {rd }}$ ed. Williams and Wilkins: Baltimore MD; 1997. p. 845-53.

69. Herent P, Stynen D, Hernando F, Fruit J, Poulain D. Retrospective evaluation of two latex agglutination tests for detection of circulating antigens during invasive candidosis. J Clin Microbiol 1992;30:215864 .

70. Chakrabarti A, Anindita Das, David JK. Molecular diagnostic methods in mycotic infections. In: Proceedings of International Symposium on "Mycotic Infections in the $21^{\text {st }}$ Century". Venugopal PV, Venugopal TV, editors. Medical Council of India: New Delhi; 2002. p. 97-134.

71. Macdonald F, Odds FC. Inducible proteinase of Candida albicans in diagnostic serology and in the pathogenesis of systemic candidosis. $\mathrm{J}$ Med Microbiol 1980;13:423-35.

72. Radhakrishnan VV, Rout SD, Mohan PK. Disseminated intra-cerebral microabscesses: A immunosuppressed study. Indian J Pathol Microbiol 1994;38:171-8.

73. Bodey GP, Vartivarian S. Aspergillosis. Eur J Clin Microbiol Infect Dis 1989;8:413-37.

74. Torre-Cisneros J, Lopez OL, Kusne S, Martinez AJ, Starzl TE, Simmons RL, et al. CNS aspergillosis in organ transplantation: A clinicopathological study. J Neurol Neurosurg Psychiatry 1993; 56:18893.

75. Walsh TJ, Hier DB, Caplan LR. Fungal infections of the central nervous system: Comparative analysis of risk factors and clinical signs in 57 patients. Neurology 1985;35:1654-7.

76. Young RC, Bennett JE, Vogel CL, Carbone PP, DeVita VT. Aspergillosis. The spectrum of the disease in 98 patients. Medicine (Baltimore) $1970 ; 49: 147-73$

77. Beal MF, O'Carroll CP, Kleinman GM, Grossman RI. Aspergillosis of the nervous system. Neurology 1982;32:473-9.

78. Beal MF. Cerebral aspergillosis. N Y State J Med 1988;88:620-2.

79. Boes B, Bashir R, Boes C, Hahn F, McConnell JR, McComb R. Central nervous system aspergillosis. Analysis of 26 patients. J Neuroimaging
1994;4:123-9.

80. Conti DJ, Rubin RH. Infection of the central nervous system in organ transplant recipients. Neurol Clin 1988;6:241-60.

81. Boon AP, Adams DH, Buckels J, McMaster P. Cerebral aspergillosis in liver transplantation. J Clin Pathol 1990;43:114-8.

82. Marr KA, Carter RA, Crippa F, Wald A, Corey L. Epidemiology and outcome of mould infections in hematopoietic stem cell transplant recipients. Clin Infect Dis 2002;34:909-17.

83. Warris A, Voss A, Abrahamsen TG, Verweij PE. Contamination of hospital water with Aspergillus fumigatus and other molds. Clin Infect Dis 2002;34:1159-60.

84. Lass-Florl C, Rath P, Niederwieser D, Kofler G, Wurzner R, Krezy $\mathrm{A}$, et al. Aspergillus terreus infections in hematological malignancies: Molecular epidemiology suggests association with in-hospital plants. J Hosp Infect 2000;46:31-5.

85. Moore CB, Sayers N, Mosquera J, Slaven J, Denning DW. Antifungal resistance to Aspergillus. J Infect 2000;41:203-20.

86. Dortzbach RK, Segrest DR. Orbital aspergillosis. Ophthalmic Surg $1983 ; 14: 240-4$.

87. Hedges TR, Leung LS. Parasellar and orbital apex syndrome caused by aspergillosis. Neurology 1976;26:117-20.

88. Slavin ML. Primary aspergillosis of the orbital apex. Arch Ophthalmol 1991;109:1502-3.

89. Wolter JR. Diagnosis and management of orbital aspergillosis. Ann Ophthalmol 1976;8:17-20.

90. Aisner J, Wiernik PH, Schimpff SC. Treatment of invasive aspergillosis: Relation of early diagnosis and treatment to response. Ann Intern Med 1977;86:539-43.

91. Surya Prakash Rao G, Mann SB, Talwar P, Arora MM. Primary mycotic infection of paranasal sinuses. Mycopathologia 1984;84:73-6.

92. Latge JP. Aspergillus fumigatus and aspergillosis. Clin Microbiol Rev 1999;12:310-50.

93. Deshpande DH, Desai AP, Dastur HM. Aspergillosis of the central nervous system. A clinical and mycopathological study of 9 cases. Neurol India $1975 ; 23: 167-75$

94. Kchir N, Bouratbine A, Boubaker S, Jemel H, Haouet S, Chatti S, et al. Cerebral aspergillotic granuloma. Apropos of a case and a review of the literature. Neurochirurgie 1990;36:132-6.

95. Linares G, McGarry PA, Baker RD. Solid solitary aspergillotic granuloma of the brain. Report of a case due to Aspergillus candidus and review of the literature. Neurology 1971;21:177-84.

96. Mohandas S, Ahuja GK, Sood VP, Virmani V. Aspergillosis of the central nervous system. J Neurol Sci 1978;38:229-33.

97. Dismukes WE, Stamm AM, Graybill JR, Craven PC, Stevens DA, Stiller RL, et al. Treatment of systemic mycoses with ketoconazole: Emphasis on toxicity and clinical response in 52 patients. National Institute of Allergy and Infectious Diseases collaborative antifungal study. Ann Intern Med 1983;98:13-20.

98. Fardoun R, Rao NK, Miskeen AK. Cerebral aspergilloma. Review of the literature apropos of a case. Neurochirurgie 1990;36:45-51.

99. Young RF, Gade G, Grinnell V. Surgical treatment for fungal infections in the central nervous system. J Neurosurg 1985;63:371-81.

100. Whelan MA, Stern J, deNapoli RA. The computed tomographic spectrum of intracranial mycosis: Correlation with histopathology. Radiology 1981;141:703-7.

101. MacCormick WF, Schochet SS Jr, Weaver PR, MacCrary JA $3^{\text {rd }}$. Disseminated aspergillosis. Aspergillus endophthalmitis, optic nerve infarction and carotid artery thrombosis. Arch Pathol 1975;99:353-9.

102. Nenoff P, Kellermann S, Horn LC, Keiner S, Bootz F, Schneider S, et al. Case report. Mycotic arteritis due to Aspergillus fumigatus in a diabetic with retrobulbar aspergillosis and mycotic meningitis. Mycoses 2001;44:407-14.

103. Endo T, Tominaga T, Konno H, Yoshimoto T. Fatal subarachnoid hemorrhage, with brainstem and cerebellar infarction, caused by Aspergillus infection after cerebral aneurysm surgery: Case report. Neurosurgery 2002;50:1147-51.

104. Case records of the Massachusetts General Hospital. Weekly clinicopathological exercises. Case 7-1988. A 27-year-old man with acute myelomonocytic leukemia in remission and repeated intracranial hemorrhages. N Eng J Med 1988;318:427-40. 
105. Seres JL, Ono H, Benner EJ. Aspergillosis presenting as spinal cord compression. J Neurosurg 1972;36:221-4.

106. Polatty RC, Cooper KR, Kerkering TM. Spinal cord compression due to an aspergilloma. South Med J 1984;77:645-8.

107. Nakazato I, Kamada Y, Taira T, Iwamasa T. Massive spinal cord necrosis associated with adult T-cell leukaemia caused by Aspergillus. Virchows Arch A Pathol Anat Histopathol 1993;423:397-400.

108. Sheth NK, Varkey B, Wagner DK. Spinal cord Aspergillus invasion - complication of an aspergilloma. Am J Clin Pathol 1985;84:763-9.

109. Wagner DK, Varkey B, Sheth NK, DaMert G.J. Epidural abscess, vertebral destruction and paraplegia caused by extending infection from an aspergilloma. Am J Med 1985;78:518-22.

110. Naim-Ur-Rahman, Jamjoom A, al-Hedaithy SS, Jamjoom ZA, alSohaibani MO, Aziz SA. Cranial and intracranial aspergillosis of sinonasal origin. Report of nine cases. Acta Neurochir (Wein) 1996;138:94450 .

111. Santosh V, Yasha TC, Khanna N, Pal L, Swamy HS, Chandramuki A, et al. Fungal infections of the nervous system - a pathological study. Neurol Infect Epidemiol 1996;1:69-79.

112. Kak VK, Banerjee AK, Radotra BD. Cerebral aspergillosis: Distinct immunosuppressed pattern in 62 cases. Neurol India 1989;37:239.

113. Banerjee AK, Singh MS, Kak VK, Talwar P, Rout D. Cerebral aspergillosis: Report of 8 cases. Indian J Path Microbiol 1977;20:919 .

114. Bahadur S, Kacker KK, D'Souza B, Chopra P. Paranasal fungal aspergillosis. J Laryngol Otol 1983;97:863-7.

115. Hazarika P, Ravikumar V, Nayak RG, Rao PS, Shivananda PG. Rhinocerebral mycosis. Ear Nose Throat J 1984;63:464-8.

116. Murthy JM, Sundaram C, Prasad VS, Purohit AK, Rammurti S, Laxmi V. Sinonasal aspergillosis: A form of central nervous system aspergillosis in south India. Mycoses 2001;44:141-5.

117. Murthy JM, Sundaram C, Prasad VS, Purohit AK, Rammurthi S, Laxmi V. Aspergillosis of the central nervous system - study of 21 cases seen in a University hospital in South India. J Assoc Physicians India 2000;48:677-81.

118. Nadkarni T, Goel A. Aspergilloma of the brain: An overview. J Postgrad Med 2005;51:S37-41.

119. Dubey A, Patwardhan RV, Sampath S, Santosh V, Sastry KV, Nanda A. Intracranial fungal granuloma: Analysis of 40 patients and review of the literature. Surg Neurol 2005;63:254-60.

120. Young RC, Bennett JE, Vogel CL, Carbone PP, DeVita VT. Aspergillosis. The spectrum of the disease in 98 patients. Medicine (Baltimore) 1970;49:147-73

121. Salaki JS, Louria DB, Chmel H. Fungal and yeast infections of the central nervous system. A clinical review. Medicine (Baltimore) 1984;63:108-32

122. Veress B, Malik OA, el-Tayeb AA, el-Daoud S, Mahgoub ES, el-Hassan AM. Further observations on the primary paranasal Aspergillus granuloma in the Sudan: A morphological study of 46 cases. Am J Trop Med Hyg 1973;22:765-72.

123. Washburn RG, Kennedy DW, Begley MG, Henderson DK, Bennett JE. Chronic fungal sinusitis in apparently normal hosts. Medicine (Baltimore) 1988;67:231-47.

124. Panda NK, Sharma SC, Chakrabarti A, Mann SB. Paranasal sinus mycoses in north India. Mycoses 1998;41:281-6

125. Srinivasan M, Gonzales CA, George C, Cevallos V, Mascarenhas JM, Asokan B, et al. Epidemiology and aetiological diagnosis of corneal ulceration in Madurai, south India. Br J Ophthalmol 1997;61:96571.

126. Al-Doory Y, Wagner GE. Aspergillosis. Thomas CC Publisher: Springfield, II; 1985.

127. de Carpentier JP, Ramamurthy L, Denning DW, Taylor PH. An algorithmic approach to Aspergillus sinusitis. J Laryngol Otol 1994;108:314-8.

128. Diamond RD, Bennett JE. Prognostic factors in cryptococcal meningitis: A study of 111 cases. Ann Intern Med 1974;80:176-81.

129. Camarata PJ, Dunn DL, Farney AC, Parker RG, Seljeskog EL. Continual intracavitary administration of amphotericin $\mathrm{B}$ as an adjunct in the treatment of Aspergillus brain abscess: Case report and review of the literature. Neurosurgery 1992;31:575-9.
130. Nadkarni TD, Desai KI, Mazumdar D, Goel A, Shenoy A. Ischemic complications after surgical resection of intracranial granuloma. J Clin Neurosci 2003;10:500-2

131. Goel A, Nadkarni T, Desai AP. Aspergilloma in the paracavernous region. Two case reports. Neurol Med Chir (Tokvo) 1996;36:733-6.

132. Sundaram C, Goel D, Uppin SG, Seethajayalakshmi, Borgohain R. Intracranial mycotic aneurysm of Aspergillus species - report of two patients with fatal outcome and review of literature. J Clin Neurosci 2007;14:882-6.

133. Radhakrishnan VV, Saraswathy A, Rout D, Mohan PK. Mycotic aneurysms of the intracranial vessels. Indian J Med Res 1994;100:22831.

134. Sundaram C, Ratnakar KS, Rao RR, Ranganadham P, Gayathri K, Dinakar I. Diffuse fulminant aspergillosis of the central nervous system. J Assoc Physicians India 1989;37:183-5.

135. Sundaram C, Lakshmi V. Pathogenesis and pathology of brain abscess. Indian J Pathol Microbiol 2006;49:317-26.

136. Tendolkar U, Sharma A, Mathur M, Ranadive N, Sachdev M. Epidural mass due to Aspergillus flavus causing spinal cord compression: A case report and brief update. Indian J Med Microbiol 2005;23:200-3.

137. Xess I, Mohanty S, Jain N, Banerjee U. Prevalence of Aspergillus species in clinical samples isolated in an Indian tertiary care hospital. Indian J Med Sci 2004;58:513-9.

138. Gartenberg G, Bottone EJ, Keusch GT, Weitzman I. Hospital-acquired mucormycosis (Rhizopus rhizopodiformis) of skin and subcutaneous tissue: Epidemiology, mycology and treatment. N Engl J Med 1978;299:1115-8.

139. Oberle AD, Penn RL. Nosocomial invasive Saksenaea vasiformis infection. Am J Clin Pathol 1983;80:885-8.

140. Ribes JA, Vanover-Sams CL, Baker DJ. Zygomycetes in human disease. Clin Microbiol Rev 2000;13:236-301.

141. Hussain S, Salahuddin N, Ahmad I, Salahuddin I, Jooma R. Rhinocerebral invasive mycosis: Occurrence in immunocompetent individuals. Eur J Radiol 1995;20:151-5.

142. Artis WM, Fountain JA, Delcher HK, Jones HE. A mechanism of susceptibility to mucormycosis in diabetic ketoacidosis: Immunosuppressed and iron availability. Diabetes 1982;31:1109-14.

143. Lopes JO, de Mello ES, Klock C. Mixed intranasal infection caused by Fusarium solani and a zygomycete in a leukaemic patient. Mycoses $1995 ; 38: 281-4$

144. Chakrabarti A, Das A, Sharma A, Panda N, Das S, Gupta KL, et al Ten years experience in zygomycosis at a tertiary care centre in India. J Infect 2001;42:261-6.

145. Sundaram C, Murthy JMK, Purohit AK, Mohan Das S. Rhinocerebral zygomyosis: A immunosuppressed study. Neurol India 1998;46:1269 .

146. Sundaram C, Mahadevan A, Laxmi V, Yasha TC, Santosh V, Murthy JM, et al. Cerebral zygomycosis. Mycosis 2005;48:396-407.

147. Weinberg WG, Wade BH, Cierny G $3^{\text {rd }}$, Stacy D, Rinaldi MG. Invasive infection due to Apophysomyces elegans in immunocompetent hosts. Clin Infect Dis 1993;17:881-4

148. Kimura M, Smith MB, McGinnis MR. Zygomycosis due to Apophysomyces elegans: Report of 2 cases and review of the literature. Arch Pathol Lab Med 1999;123:386-90.

149. Revankar SG, Sutton DA, Rinaldi MG. Primary central nervous system phaeohyphomycosis: A review of 110 cases. Clin Infect Dis 2004;38:20616.

150. Casadevall A, Rosas AL, Nosanchuk JD. Melanin and virulence in Cryptococcus neoformans. Curr Opin Microbiol 2000;3:354-8.

151. Dixon DM, Polak A, Szaniszlo PJ. Pathogenicity and virulence of wildtype and melanin-deficient Wangiella dermatitidis. J Med Vet Mycol 1987;25:97-106

152. Feng B, Wang X, Hauser M, Kaufmann S, Jentsch S, Haase G, et al Molecular cloning and characterization of WdPKS1, a gene involved in dihydroxynaphthalene melanin biosynthesis and virulence in Wangiella (Exophiala) dermatitidis. Infect Immun 2001;69:1781-94.

153. Schnitzler N, Peltroche-Llacsahuanga H, Bestier N, Zundorf J, Lutticken R, Haase G. Effect of melanin and carotenoids of Exophiala (Wangiella) dermatitidis on phagocytosis, oxidative burst and killing by human neutrophils. Infect Immun 1999;67:94-101. 
154. Kwon-Chung KJ, Polacheck I, Popkin TJ. Melanin-lacking mutants of Cryptococcus neoformans and their virulence for mice. J Bacteriol 1982;150:1414-21.

155. Jacobson ES. Pathogenic roles for fungal melanins. Clin Microbiol Rev 2000;13:708-17.

156. Butler MJ, Day AW. Fungal melanins: A review. Can J Microbiol 1998;44:1115-36.

157. Hamilton AJ, Gomez BL. Melanins in fungal pathogens. J Med Microbiol 2002;51:189-91.

158. Crichlow DK, Enrile FT, Memon MY. Cerebellar abscess due to Cladosporium trichoides (Bantianum): Case report. Am J Clin Pathol 1973;60:416-21.

159. Middleton FG, Jurgenson PF, Utz JP, Shadomy S, Shadomy HJ. Brain abscess caused by Cladosporium trichoides. Arch Intern Med 1976;136:444-8.

160. Bennett JE, Bonner H, Janning AE, Lopez RI. Chronic meningitis caused by Cladosporium trichoides. Am J Clin Pathol 1973;59:398-407.

161. Salem FA, Kannangara DW, Nachum R. Cerebral chromomycosis. Arch Neurol 1983;40:173-4.

162. Scaravilli F. Parasitic and fungal infections. In: Greenfield's neuropathology. Adams JH, Duchen LW, editors. $5^{\text {th }}$ ed, Edward Arnold: London; p. 400-46.

163. Santosh V, Yasha TC, Khanna N, Pal L, Swamy HS, Chandramuki A, et al. Fungal infections of the nervous system: A pathological study. Neurol Infect Epidemiol 1996;1:69-79.

164. Bagchi A, Aikat BK, Barua D. Granulomatous lesion of the brain due to Cladosporium trichoides. J Indian Med Assoc 1962;38:602-4.

165. Dastur HM, Chaukar AP, Rebello MD. Cerebral chromoblastomycosis due to Cladosporium trichoides (Bantianum) I (A review and case report). Neurol India 1966;14:1-5.

166. Sandhyamani S, Bhatia R, Mohapatra LN, Roy S. Cerebral cladosporiosis. Surg Neurol 1981;15:431-4.

167. Sujatha AP, Mhatre HC. Primary chromoblastomycosis of brain: A case report. Indian J Pathol Microbiol 1981;24:61-6.

168. Chandramukhi A, Ramadevi MG, Shankar SK. Cerebral cladosporiosis: A neuropathological and microbiological study. Clin Neurol Neurosurg $1983 ; 85: 245-53$.

169. Jayakeerthi A, Dias M, Nagarathna S, Anandh B, Mahadevan A, Chandramuki A. Brain abscess due to Cladophialophora bantiana. Indian J Med Microbiol 2004;22:193-5.

170. Santosh V, Khanna N, Shankar SK, Pal L, Das S, Chandramukhi A, et al. Primary mycotic abscess of the brain caused by Fonsecaea pedrosoi. Case report. J Neurosurg 1995;82:128-30.
171. Banerjee TK, Patwari AK, Dutta R, Anand VK, Chabra A. Cladosporium bantianum meningitis in a neonate. Indian J Pediatr 2002;69:721-3.

172. Gupta SK, Manjunath-Prasad KS, Sharma BS, Khosla VK, Kak VK, Minz M, et al. Brain abscess in renal transplant recipients: Report of three cases. Surg Neurol 1997;48:284-7.

173. Vyas MC, Joshi YR, Bhargava N, Joshi KR, Tanwar RK. Cerebral chromoblastomycosis: A rare case report of cerebral abscess and brief review of literature. Indian J Pathol Microbiol 2000;43:81-5.

174. Deng ZL, Connor DH. Progressive disseminated penicilliosis caused by Penicillium marneffei report of eight cases and differentiation of the causative organism from $\mathrm{H}$ istoplasma capsulatum. Am J Clin Pathol 1985;84:323-7.

175. Chang CC, Liao ST, Huang WS, Liu JD, Shih LS. Disseminated Penicillium marneffei infection in a patient with acquired immunodeficiency syndrome. Formos Med Assoc 1995;94:572-5.

176. Singh PN, Ranjana K, Singh YI, Singh KP, Sharma SS, Kulachandra $\mathrm{M}$, et al. Indigenous disseminated Penicillium marneffei infection in the state of Manipur, India: Report of four autochthonous cases. J Clin Microbiol 1999;37:2699-702.

177. Ranjana KH, Priyokumar K, Singh TJ, Gupta CH, Sharmila L, Singh PN, et al. Disseminated Penicillium marneffei infection among HIVinfected patients in Manipur state, India. J Infect 2002;45:268-71.

178. Kwon-Chung KJ, Bennett JE. Medical mycology. Lea and Febiger: Philadelphia; 1992.p. 866.

179. Bauserman SC, Schochet Jr SS. Bacterial, fungal and parasitic diseases of the central nervous system. In: Principles and practice of neuropathology. Nelson JS, Parisi JE, Schochet SS Jr, editors. Chapter 3. Mosby: London; 1993. p. 42-74

180. Natarajan M, Balakrishnan D, Muthu AK, Arumugham K. Maduramyeosis of the brain: Case report. J Neurosurg 1975;42:229 31.

181. Casadevall A, Steenbergen JN, Nosanchuk JD. 'Ready made' virulence and 'dual use' virulence factors in pathogenic environmental fungi: The Cryptococcus neoformans paradigm. Curr Opin Microbiol 2003;6:332-7.

182. Mylonakis E, Ausubel FM, Perfect JR, Heitman J, Calderwood SB. Killing of Caenorhabditis elegans by Cryptococcus neoformans as a model of yeast pathogenesis. Proc Natl Acad Sci USA 2002;99:15675-80.

Accepted on 07-07-2007

Source of Support: Nil, Conflict of Interest: None declared. 